\title{
MAGMATIC AND HYDROTHERMAL PLATINUM-GROUP MINERALS AND BASE-METAL SULFIDES IN THE BAULA COMPLEX, INDIA
}

\author{
ThIERRY AUGÉ§ ${ }^{\S}$ IGNACE SALPETEUR ANd LAURENT BAILLY \\ BRGM, BP 6009, F-45060 Orléans Cedex 2, France \\ Murari Mohan MUKHERJEE ${ }^{\mathbb{I l}}$ and Rabindra Nath PATRA \\ Geological Survey of India, Unit VIII, Nayapalle, Bhubaneswar 751012, Orissa, India
}

\begin{abstract}
The $3 \times 0.5 \mathrm{~km}$ gabbro-hosted Precambrian Baula Complex, in Orissa, India, comprises a steeply dipping pyroxenite unit in tectonic contact to the east with a peridotite unit that contains three chromitite layers and that becomes pyroxene-rich eastward toward the top. The ultramafic formations are intruded by the Bangur Gabbro, the top of which entered a shear zone, forming a breccia zone. The breccia, 1 to $40 \mathrm{~m}$ thick and almost continuous along strike for $2000 \mathrm{~m}$, shows extensive vertical and lateral variations. It is made up of ultramafic blocks of various sizes derived from the Baula Complex within a matrix of hydrothermally altered Bangur Gabbro. The brecciation process has affected one of the chromitite layers. Two categories of platinum-groupelement (PGE) mineralization have been observed in the Baula Complex, both associated with the Bangur Gabbro. The first (type 1) occurs within a sulfide-free magmatic environment within the Bangur Gabbro near its contact with the peridotite, and is clearly formed within a magmatic environment. The PGE-bearing rock contains relics of dunite and chromitite extracted mechanically from the ultramafic formations by the intrusive gabbro. This mineralization is dominated by $\mathrm{Pt}(\mathrm{Pt} / \mathrm{Pd}$ in the range $8-9)$, is anomalous in $\mathrm{Rh}$, and the platinum-group-mineral (PGM) assemblage is dominated by isoferroplatinum, braggite and malanite, with sperrylite and laurite, included in pyroxene and plagioclase. The second category (types $2 \mathrm{~A}$ and $2 \mathrm{~B}$ ) is restricted to the hydrothermally altered matrix of the breccia zone. Type 2A has PGE associated with base-metal mineralization; the PGE assemblages are characterized by $\mathrm{Pd}(\mathrm{Pt} / \mathrm{Pd} 0.5)$, and the PGM are mainly sudburyite, minerals of the system $\mathrm{Pd}-\mathrm{Bi}-\mathrm{Te}-\mathrm{Sb}$, and sperrylite. Type $2 \mathrm{~B}$ is not associated with base metals, the PGE are characterized by $\mathrm{Pt}(\mathrm{Pt} / \mathrm{Pd}$ in the range 2-3), and PGM phases of the Pt-Sb-As system (geversite, sperrylite) coexist with Pd antimony (mertieite-II). The PGE minerals form discrete grains, a) in the hydrous silicate matrix (commonly as clusters) without base-metal sulfides (BMS) or in the silicate matrix accompanying BMS trails, where they are in some cases adjacent to disseminated BMS, b) within ferrian chromite, c) within BMS in silicates, and d) within or adjacent to BMS in ferrian chromite. We present the results of electron-microprobe analyses of the PGM and BMS phases, and propose a model in which type- 1 mineralization results from an orthomagmatic episode, whereas the type- 2 mineralization is a result of hydromagmatic processes affecting the gabbroic matrix of the complex breccia zone.
\end{abstract}

Keywords: platinum-group minerals, platinum-group elements, breccia, magmatic deposit, hydrothermal deposit, Baula Complex, Orissa, India.

\section{SOMMAIRE}

Le complexe précambrien de Baula, dans l'état d'Orissa, en Inde, long de $3 \mathrm{~km}$ et large de $0.5 \mathrm{~km}$, encaissé dans un gabbro, comprend une unité de pyroxénite à fort pendage en contact tectonique avec, à l'est, une unité de péridotite qui renferme trois couches de chromite. Vers son sommet, l'unité de péridotite s'enrichit en pyroxène. Les formations ultramafiques sont recoupées par le gabbro de Bangur. A son sommet, l'intrusion de gabbro se met en place dans une zone de cisaillement. Ce cisaillement développe une zone de brèche dont le gabbro est le ciment. Cette brèche, puissante de 1 à $40 \mathrm{~m}$, est presque continue sur $2000 \mathrm{~m}$ mais montre des variations verticales et latérales importantes. Elle est constituée de blocs de différentes tailles provenant des formations ultramafiques, dans une matrice qui correspond au gabbro de Bangur transformé par altération hydrothermale. De plus, la bréchification a affecté une des couches de chromite. Deux types de minéralisation en éléments du groupe du platine (EGP) ont été reconnus dans le complexe de Baula, tous deux associés au gabbro de Bangur. Le premier (type 1) est situé dans ce gabbro près du contact avec l'unité ultramafique, dans un environnement magmatique, sans sulfure de métaux de base. Le niveau minéralisé en EGP contient des blocs de dunite et de chromitite, extraits du niveau ultramafique lors de la mise en place du gabbro. Cette minéralisation est à $\mathrm{Pt}$ dominant (Pt/Pd 8-9), avec une anomalie en $\mathrm{Rh}$. Les minéraux du groupe du platine (MGP)

§ E-mail address: t.auge@brgm.fr

II Present address: Geological Survey of India, A.M.S.E. Wing, Dayanand Sagar College Road, Bangalore 560078, Karnataka, India 
sont principalement isoferroplatine, braggite et malanite, avec sperrylite and laurite, inclus dans les pyroxènes et le plagioclase du gabbro. Le second type (subdivisé en 2A et 2B) est exclusivement associé à la matrice de la zone de brèche, montrant les effets d'une recristallisation hydrothermale. Le type $2 \mathrm{~A}$ est associé à une minéralisation en sulfures de métaux de base; il est à Pd dominant (Pt/Pd 0.5), avec principalement sudburyite, des minéraux du système $\mathrm{Pd}-\mathrm{Bi}-\mathrm{Te}-\mathrm{Sb}$, et sperrylite. Le type $2 \mathrm{~B}$ est sans sulfure de métaux de base, à Pt dominant ( $\mathrm{Pt} / \mathrm{Pd} 2-3$ ) avec des minéraux du système $\mathrm{Pt}-\mathrm{Sb}-\mathrm{As}$ (geversite, sperrylite) qui coexistent avec un composé de $\mathrm{Pd}-\mathrm{Sb}$ (mertieite-II). Les minéraux du groupe du platine sont sous forme de grains soit a) dans les silicates hydratés ou hydroxylés de la matrice, généralement regroupés en essaims, sans sulfure de métaux de base, ou accompagnant (parfois accolés) des traînées de sulfures de métaux de base, b) dans de la chromite ferrifère, c) dans des sulfures de métaux de base dans les silicates, et d) dans ou accolés aux sulfures de métaux de base dans la chromite ferrifère. Dans cet article, nous présentons les résultats d'une étude des minéraux du groupe du platine et des sulfures de métaux de base, et nous présentons un modèle où la minéralisation de type 1 est considérée comme orthomagmatique, alors que les minéralisations de types $2 \mathrm{~A}$ et $2 \mathrm{~B}$ sont considérées comme résultant d'un processus "hydromagmatique" qui affecte la matrice gabbroïque de la zone de brèche.

Mots-clés: minéraux du groupe du platine, éléments du groupe du platine, brèche, gisement magmatique, gisement hydrothermal, complexe de Baula, Orissa, Inde.

\section{INTRODUCTION}

The Baula Complex (also known as the BaulaNuasahi or Nausahi Complex), located approximately $170 \mathrm{~km}$ north-northeast of Bhubaneswar, the capital of Orissa State, India (Fig. 1), hosts several active mines working high-grade chromite deposits. The potential of this complex for platinum-group elements (PGE) was tested in the late 1980s and 1990s by the Geological Survey of India (GSI), and the mineralized units were identified (Thiagarajan et al. 1989, Nanda et al. 1996, Patra \& Mukherjee 1996). A later survey under a joint GSI-BRGM Co-operation Agreement confirmed the PGE potential of the Baula sector, and the PGM occurrences were reported by Mondal \& Baidya (1997), and Augé et al. (1999).

In this paper, we describe the platinum-group minerals (PGM) and base-metal sulfides (BMS) discovered in the complex. We conclude that there are two types of mineralization, one of magmatic origin, the other of hydrothermal origin, both linked to the intrusion of a gabbro into the ultramafic complex.

\section{The Baula Complex}

\section{Geological setting}

The Baula Complex is an ultramafic body hosted by a large gabbro unit, and is located in the southeastern part of the Archean Singhbhum craton. It is one of several ultramafic intrusive bodies clustered near the central-south margin of the craton, one of which (Sukinda) is a major producer of chromite (Banerjee 1972). Banerjee et al. (1987) attributed these bodies to a mantle plume that rose below the Archean crust prior to a major thrusting event in late Proterozoic time between the Eastern Ghats Mountains to the south and the Archean Singhbhum nucleus to the north.

The Baula ultramafic complex, an elongate body 3 $\mathrm{km}$ long by $0.5 \mathrm{~km}$ wide, trends generally NNW in its northern part and N-S in its southern part (Fig. 1). It is hosted by a large body of gabbro belonging to the Gab-
bro-Anorthosite Unit (Saha 1994) and is partly concealed by the Tertiary cover that parallels the shoreline of the Bay of Bengal. The gabbro of the Gabbro-Anorthosite Unit is medium-grained, isotropic to weakly layered, and locally contains a thick layer of magnetite. Relationships between it and the ultramafic units cannot be clearly established because of the lack of exposure. To the south, the Baula Complex is cut by the coarse-grained Bangur gabbro.

\section{Ultramafic formations}

The Baula Complex contains the following sequence of units, which were defined as Suite 1 by Mondal et al. (2001) (Figs. 1, 2).

The Footwall pyroxenite is a linear body, $2 \mathrm{~km}$ long and close to $50 \mathrm{~m}$ thick, comprising coarse-grained orthopyroxenite with an adcumulate texture. The contact with the footwall gabbro is not exposed.

The chromitite-bearing peridotite and chromitite lodes, with an estimated thickness of 120-150 m, constitute the core of the ultramafic complex. It hosts three layers of chromitite (lodes): Durga, the lowest and furthest west, Laxmi in the center, and Ganga-Shankar, the highest and furthest east (Mukherjee \& Haldar 1975, Mondal et al. 2001, and Figs. 1, 2). The unit is composed partly of dunite (olivine adcumulate), and some peridotite contains orthopyroxene as a cumulus phase. Both ortho- and clinopyroxene increase in abundance toward the top of the unit, where they locally cause a marked mineral layering that strikes $\mathrm{N} 20^{\circ} \mathrm{W}$ and dips $65^{\circ} \mathrm{E}$. Olivine is absent at some localities, resulting in a pyroxenite end-member; the proportion of pyroxene generally increases toward the top of the cumulate sequence. The peridotite is partly $(10 \%)$ to wholly serpentinized.

The top of the ultramafic sequence is marked by a pyroxene-rich unit that contains the Ganga-Shankar chromitite layer, but the contact between this unit and the hanging-wall gabbro is obscured by the injection of Bangur Gabbro along a N-S shear and breccia zone (as described below). In the north, beyond a major dextral 


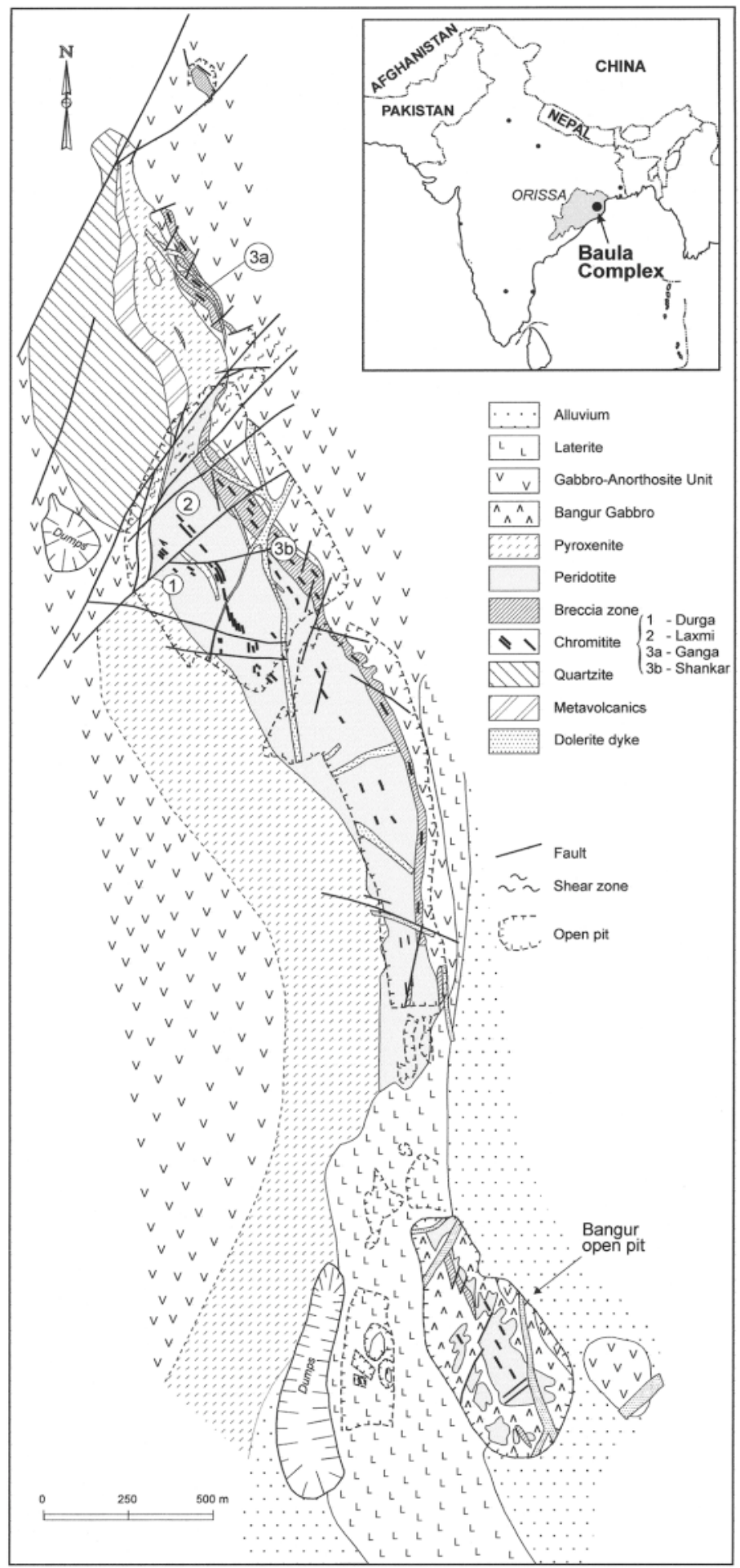

FIG. 1. Location and geology of the Baula Complex, Orissa, India. 
shear-zone in the Ganga sector, the peridotite sequence is truncated, and the two basal layers of chromitite disappear. In the south, in the Bangur sector, the chromitite layers are totally dismembered by sinistral and dextral faults (Fig. 1).

The Durga lode (average thickness 5-6 m) consists of both massive and layered chromitite with a cumulus texture. The massive ore, in particular, has a characteristic texture consisting of "nodules" (1-2 cm diameter) of euhedral fine-grained chromite in a silicate matrix contained within coarse-grained massive chromitite. The Laxmi lode also has a cumulus texture, with interstitial relics of olivine and clinopyroxene amongst the chromite grains. The two lodes are separated by a massive layer of dunite 30-50 m thick; contacts between the chromitites and the dunite vary from sharp to transitional. The most massive layers of chromitite (2-3 m thick) are worked for "lumpy" ore. The present discontinuity between the Durga and Laxmi chromitite layers results from a late tectonic event that affected the Complex (A. Genna and T. Augé, unpubl. data).

The Ganga-Shankar lode is dismembered throughout its length by the complex shear-zone into which the Bangur Gabbro has been injected in the form of a mag- matic breccia (A. Genna and T. Augé, unpubl. data). The lode consists of chromitite blocks of variable texture, shape and size in a complex gabbro matrix (Fig. 3). The largest blocks vary in size from $50 \mathrm{~cm}$ to $5 \mathrm{~m}$ (Figs. $3 \mathrm{~A}, \mathrm{~B}$ ); overall, the textures of the chromitite are similar to those of the Ganga and Laxmi layers. Individual blocks are extracted from the barren matrix by the miners.

\section{The Bangur Gabbro and Breccia Zone}

The Bangur Gabbro intrudes the Gabbro-Anorthosite Unit and the southern part of the ultramafic formation in the Baula Complex (Fig. 1). It is a coarsegrained gabbronorite, with large euhedral cumulus plagioclase and pyroxene crystals (up to $1 \mathrm{~cm}$ across). It contains xenoliths of dunite and chromitite of variable size and shape incorporated from the host ultramafic unit. Locally, the chromitite in the gabbro takes the form of concentrations of nodules ranging in diameter from less than $1 \mathrm{~cm}$ to $10 \mathrm{~cm}$. In some places, chromitite is disseminated in the gabbro, forming a "chromitiferous" gabbro, and such incorporation may be accompanied by the transformation of chromite into a magnetic mineral

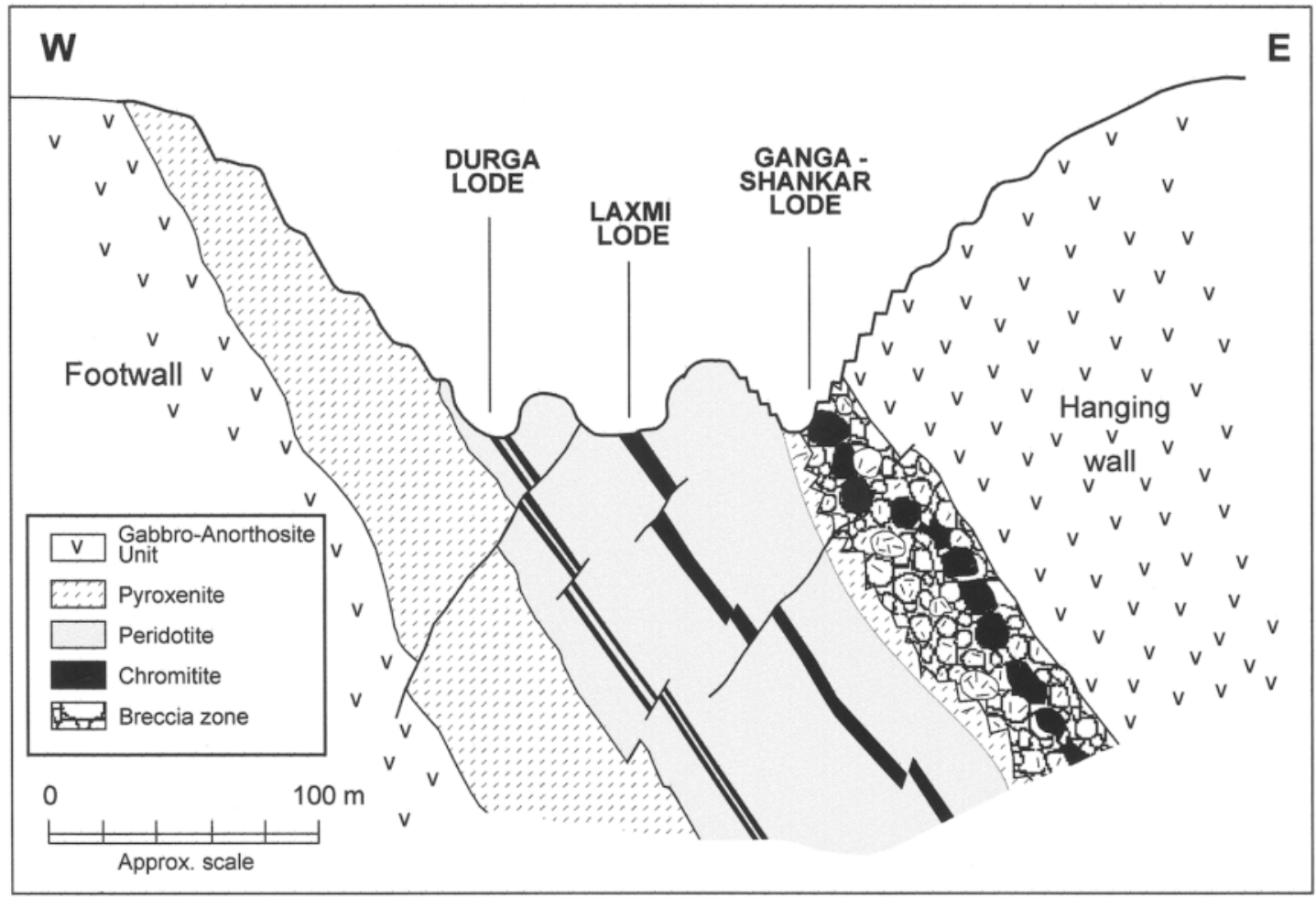

FIG. 2. Cross section through one of the northern open pits in the Baula Complex, showing the Breccia zone and the three chromitite lodes. 

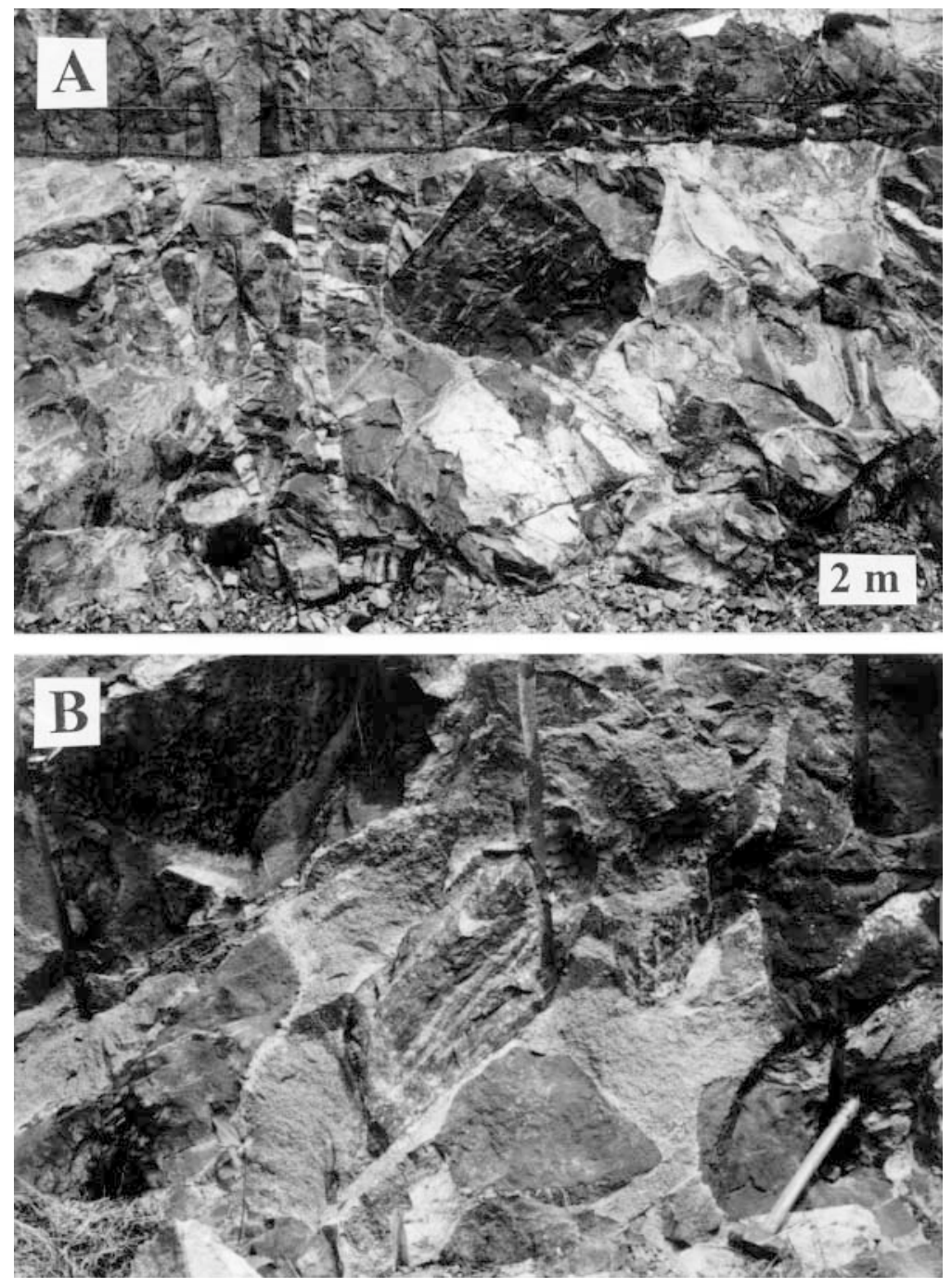

FIG. 3. The Breccia zone of the Baula Complex. A) View of the breccia and hanging wall (Shankar open pit) showing large boulders of chromitite (black) and blocks of various forms cut by a dyke. The fencing on the bench is about $2 \mathrm{~m}$ high. B) Detailed view of the breccia with blocks of various nature (including layered ferrian chromite, center) in a gabbro matrix.

that is similar to what has been called "ferritchromit". The term "ferritchromit" is used in the literature to describe a complex two-phase intergrowth (Wylie et al. 1987, Shen et al. 1988, Mitra et al. 1992, Burkhard 1993, Mohanty \& Sahoo 1996) that was also known as donathite (subsequently identified as a mixture of two spinels by Burns et al. 1997). The use of both terms is disapproved by the IMA, and R.F. Martin (written commun., 2002) suggests using the term "ferrian chromite" to describe this complex inframicrometric assemblage of minerals. It should be noted, however, that this magnetic assemblage does not correspond to a chromite enriched in trivalent iron but to the destabilization of a pre-existing chromite into different mineral species, which probably include magnetite. Nevertheless, as the term "ferrian chromite" was used by Mondal et al. (2001) for this complex intergrowth (i.e., "the alteration product of pre-existing chromite that now con- 
tains several types of inclusions") we shall, for the time being, continue to use this term.

Disseminated chromite and ferrian chromite crystals are very often included in cumulus plagioclase, suggesting that the chromite crystals were incorporated early in the magmatic process, before plagioclase crystallization. Transformation of chromite into the magnetic phase (ferrian chromite), therefore, probably results from a very high (liquidus) temperature reaction between chromite and the silicate magma.

In the structurally higher part of the intrusion, the Bangur Gabbro was emplaced along a major shear-zone in the form of a magmatic breccia (A. Genna and T. Augé, unpubl. data). The breccia zone is 1 to $40 \mathrm{~m}$ thick, almost continuous over a length of $2000 \mathrm{~m}$, and shows marked vertical and lateral variations (Fig. 1). The breccia cuts obliquely across the ultramafic succession, in particular at the level of the Ganga-Shankar chromite layer, which has been dislocated, although not completely disturbed. The Durga and Laxmi chromitite lodes are stratiform in the dunite, but the GangaShankar lode is cut into large parallel blocks in a gabbro matrix (Fig. 3). At other localities in the zone, the breccia clasts are mainly blocks composed of host dunite, pyroxenite or chromitite, depending on the unit affected by shearing. The breccia matrix is pyroxene-rich gabbro that locally becomes pyroxenite, with a hypidiomorphic, commonly porphyritic texture of cumulus plagioclase and pyroxene. The chromitite was progressively finely fragmented and gradually incorporated into the gabbro matrix during the brecciation process. A description of the breccia zone has recently been given by Mondal et al. (2001). The observed progressive incorporation of large blocks of dunite and chromitite into the gabbro, the style of the breccia, and unpublished geochemical data, all confirm that the gabbro matrix is part of the Bangur Gabbro.

The gabbro also shows the affects of a hydrothermal episode that was part of the late magmatic evolution. The intensity of the alteration increases toward the top of the magmatic system, particularly in the breccia zone. This hydrothermal episode is marked by the development of secondary hydrous minerals, such as amphiboles and micas, and also by the local transformation of chromite into ferrian chromite, but the magmatic textures are preserved. It also led to the precipitation of base-metal sulfides and platinum-group minerals.

\section{MineRALIZATION}

\section{Analytical methods}

Platinum-group minerals were sought in rock samples shown by ICP-MS analyses to have high PGE contents, in several samples of chromitite and in two alluvial concentrates. The PGM are very small in size, and a scanning electron microscope (SEM) equipped with a back-scattered electron (BSE) detector was used to locate the particles on polished sections. The PGM and BMS were analyzed with a Cameca SX 50 electron microprobe.

Two programs were used for the PGM analyses. The first, utilized for most compositions, with analytical settings for 22 elements, was used at an acceleration voltage of $20 \mathrm{kV}$, a beam current of $20 \mathrm{nA}$, and a counting time of $10 \mathrm{~s}$. Pure metals standards were used, plus $\mathrm{FeS}_{2}$ for $\mathrm{Fe}$ and $\mathrm{S}, \mathrm{PbS}$ for $\mathrm{Pb}, \mathrm{Cr}_{2} \mathrm{O}_{3}$ for $\mathrm{Cr}, \mathrm{SnO}_{2}$ for $\mathrm{Sn}$,

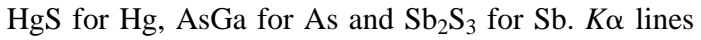
were used for $\mathrm{Ni}, \mathrm{Cu}, \mathrm{Co}, \mathrm{Cr}$ and $\mathrm{S}$, the $K \beta$ line for $\mathrm{Fe}$, $L \alpha$ lines for $\mathrm{Sn}, \mathrm{Sb}, \mathrm{Cd}, \mathrm{Se}, \mathrm{Te}, \mathrm{Ir}, \mathrm{Ru}, \mathrm{Rh}, \mathrm{Pt}$ and $\mathrm{Au}$, $L \beta$ lines for $\mathrm{Pd}$, As and $\mathrm{Os}$, and $\mathrm{M \alpha}$ lines for $\mathrm{Pb}, \mathrm{Hg}$ and $\mathrm{Bi}$. Under these conditions, the calculated detectionlimit was $\leq 0.10 \mathrm{wt} . \%$ for most elements, around 0.20 wt. \% for $\mathrm{Pt}, \mathrm{Pd}, \mathrm{Pb}$ and $\mathrm{Ir}$, and around $0.30 \mathrm{wt} . \%$ for $\mathrm{Fe}$, $\mathrm{Au}$ and Os. These values are considered acceptable for the mineralogical discussion that follows.

The second program included only 12 elements and was used mainly to analyze $\mathrm{Au}$ - and Ag-bearing minerals, avoiding interference between the $\operatorname{Ag} L \alpha$ and $\operatorname{Pd} L \beta$ lines. Analytical settings were similar to those of the first program, except that the $L \alpha$ line was used for Pd, and the $L \beta$ line and a pure metal standard for Ag. The detection limit was estimated at $0.25 \mathrm{wt} . \%$ for $\mathrm{Ag}$ and 0.27 wt. \% for $\mathrm{Au}$.

A third program was used to analyze base-metal ore minerals and to test for traces of Pt, Pd and Rh. It included analytical settings for 19 elements, and was used at an acceleration voltage of $20 \mathrm{kV}$, a beam current of $20 \mathrm{nA}$, and a counting time of $10 \mathrm{~s}$ for all the elements except PGE (40 s). Pure metals were used as standards, plus $\mathrm{FeS}_{2}$ for $\mathrm{Fe}$ and $\mathrm{S}, \mathrm{PbS}$ for $\mathrm{Pb}, \mathrm{Cr}_{2} \mathrm{O}_{3}$ for $\mathrm{Cr}, \mathrm{SnO}_{2}$ for $\mathrm{Sn}, \mathrm{HgS}$ for $\mathrm{Hg}$, AsGa for $\mathrm{As}, \mathrm{Sb}_{2} \mathrm{~S}_{3}$ for $\mathrm{Sb}$ and $\mathrm{ZnS}$ for $\mathrm{Zn}$. $K \alpha$ lines were used for $\mathrm{Ni}, \mathrm{Cu}, \mathrm{Co}, \mathrm{Fe}, \mathrm{Zn}, \mathrm{Cr}$ and $\mathrm{S}, L \alpha$ lines for $\mathrm{Sb}, \mathrm{As}, \mathrm{Te}, \mathrm{Rh}, \mathrm{Pt}, \mathrm{Pd}$ and $\mathrm{Ag}$, and $M \alpha$ lines for $\mathrm{Pb}, \mathrm{Hg}, \mathrm{Bi}$ and $\mathrm{Au}$. Detection limits were approximately 0.05 wt. $\%$ for $\mathrm{Fe}, \mathrm{Cu}, \mathrm{Co}$ and $\mathrm{Cr}, 0.10$ wt. \% for the other elements, and estimated to be around 0.05 wt.\% for Rh and Pd, and 0.10 wt.\% for Pt. The tables of analytical results do not show values below the detection limits.

\section{Types of mineralization}

PGE mineralization in the Baula Complex occurs in two environments, both associated with the Bangur Gabbro.

The first type of mineralization is Pt-dominant and restricted to the basal part of the Bangur Gabbro, where chromitite has been incorporated into the gabbro as nodules. It is sulfide-free (Table 1), and classified as Type 1 ; in this paper, we will demonstrate its magmatic origin.

The second type is Pd-dominant and occurs in the gabbro matrix of the breccia zone in hydrothermally altered rock, where it is usually associated with basemetal sulfides and ferrian chromite (Das et al. 1994, 
Nanda et al. 1996, Patra \& Mukherjee 1996, Mondal \& Baidya 1997, Mukherjee et al. 1998). For purposes of classification, it can be subdivided into Type 2A (BMSrich) and Type 2B (BMS-free), as shown in Tables 1 and 2. Some variants have been observed, as described below. In this paper, we will demonstrate that Types $2 \mathrm{~A}$ and $2 \mathrm{~B}$ are of hydrothermal origin.

\section{Type 1}

Platinum-group elements are commonly present in the Bangur Gabbro close to the contact with the ultra- mafic facies, and more specifically where the gabbro contains centimeter-sized xenoliths of chromite and ferrian chromite. Type 1 is characterized by very high Pt contents (up to $14 \mathrm{ppm}$ ) and relatively low Pd contents (between 0.8 and $1 \mathrm{ppm}$ ), high $\mathrm{Pt} / \mathrm{Pd}$ values, between 8 and 9, low Au contents and no base-metal sulfides (Table 1). Other facies of the Bangur Gabbro, away from the contact, are devoid of PGE.

A chondrite-normalized PGE pattern for a selected sample of Type 1 is shown in Figure 4 (representative PGE data are given in Table 3) and has an uncommon shape, with a positive slope from $\mathrm{Os}$ to $\mathrm{Rh}$, followed by a negative slope from $\mathrm{Rh}$ to $\mathrm{Au}$.

TABLE 1. THE MAIN CHARACTERISTICS OF THE TYPES OF PGE MINERALIZATION, AND PGM ASSEMBLAGES, BAULA COMPLEX, INDIA

\begin{tabular}{|c|c|c|c|c|}
\hline Mineralization type & & 1 & $2 A$ & $2 B$ \\
\hline ferrian chromite & & $\bullet$ & $\bullet$ & 0 \\
\hline chromite & & - & & \\
\hline sulfide & & & $\bullet$ & \\
\hline Pt & & 0 & - & $\bullet$ \\
\hline Pd & & $\bullet$ & O & $\bullet$ \\
\hline Au & & & $\bullet$ & \\
\hline $\mathrm{Pt} / \mathrm{Pd}$ & & $8-9$ & 0.5 & $2-3$ \\
\hline$\overline{\text { PGM }}$ & & & & \\
\hline isoferroplatinum & $\mathrm{Pt}_{3} \mathrm{Fe}$ & - & & \\
\hline braggite & $(\mathrm{Pt}, \mathrm{Pd}, \mathrm{Ni}) \mathrm{S}$ & $\bullet$ & & $\bullet$ \\
\hline sperryllte & $\mathrm{PtAs}_{2}$ & $\bullet$ & $\bullet$ & $\bullet$ \\
\hline geversite & $\operatorname{Pt}(\mathrm{Sb}, \mathrm{Bi})_{2}$ & & & O \\
\hline malanite & $\mathrm{Cu}(\mathrm{Pt}, \mathrm{Ir})_{2} \mathrm{~S}_{4}$ & 0 & & \\
\hline $\mathrm{Ni}$-dominant analogue of & $\mathrm{Ni}(\mathrm{Rh}, \mathrm{Pt})_{2} \mathrm{~S}_{4}$ & $\bullet$ & & \\
\hline moncheite & $(\mathrm{Pt}, \mathrm{Pd})(\mathrm{Te}, \mathrm{Bi})_{2}$ & & & $\bullet$ \\
\hline mertieite-11 & $\mathrm{Pd}_{81}(\mathrm{Sb}, \mathrm{As})_{3}$ & & $\bullet$ & $\bullet$ \\
\hline sudburyite & $(\mathrm{Pd}, \mathrm{Ni}) \mathrm{Sb}$ & & 0 & \\
\hline merenskyite & $(\mathrm{Pd}, \mathrm{Pt})(\mathrm{Te}, \mathrm{Bi})_{2}$ & & $\bullet$ & \\
\hline laurite & Rus $_{2}$ & $\bullet$ & $\bullet$ & $\bullet$ \\
\hline osmium * & Os,ir & & & \\
\hline hollingworthite & $(\mathrm{Rh}, \mathrm{Pt}, \mathrm{Pd}) \mathrm{AsS}$ & $\bullet$ & $\bullet$ & - \\
\hline unt & $\mathrm{Pd}(\mathrm{Sb}, \mathrm{Te}, \mathrm{Bi})$ & & - & \\
\hline un2 & $(\mathrm{Pd}, \mathrm{Ni})_{3}(\mathrm{Sb}, \mathrm{Te})_{4}$ & & $\bullet$ & \\
\hline un3 & $\mathrm{Pd}, \mathrm{Ag}, \mathrm{Sb}, \mathrm{Te}, \mathrm{Bi}$ & & $\bullet$ & \\
\hline stiboan merenskyite un4 & $\mathrm{Pd}_{2}(\mathrm{Te}, \mathrm{Sb}, \mathrm{BI})_{3}$ & & $\bullet$ & \\
\hline bismuthoan merenskyite un5 & $\mathrm{Pd}\left(\mathrm{Te}_{\mathrm{e}}, \mathrm{Bi}, \mathrm{Sb}\right)_{2}$ & & $\bullet$ & \\
\hline bismuthoan sudburyite un7 & $\mathrm{Pd}(\mathrm{Sb}, \mathrm{Bi}, \mathrm{Te})$ & & - & \\
\hline potarite & $\mathrm{PdHg}$ & $\bullet$ & & \\
\hline argentian gold & $\mathrm{Au}, \mathrm{Ag}$ & & $\bullet$ & \\
\hline $\begin{array}{l}\text { Type 1: Magmatic, gabbro wit } \\
\text { Type 2A: Hydrothermal, base } \\
\text { generally present to abundant } \\
\text { Type 2B: Hydrothermal, ferria }\end{array}$ & $\begin{array}{l}\text { chromite and ferri } \\
\text { letal sulfide prese }\end{array}$ & & $a b c$ & \\
\hline $\begin{array}{l}\text { Symbol size reflects the relat } \\
\text { "Present only as inclusion in }\end{array}$ & $\begin{array}{l}\text { bundance of } e \\
\text { omite }\end{array}$ & & & \\
\hline
\end{tabular}


The PGE-rich rocks are unaltered or show only weak hydrothermal alteration, and they contain chromite nodules that represent xenoliths produced by the incorporation of chromitite layers at a high temperature. Locally, chromitite has been dismembered within the gabbro and forms disseminated crystals of chromite (up to $10 \mathrm{vol} . \%$ )

TABLE 2. EXAMPLES OF THE PARAGENETIC SEQUENCE OF BASE-METAL ORE MINERALS IN THE HYDROTHERMAL MINERALIZATION AND HOST GABBRO, BAULA COMPLEX, INDIA

\begin{tabular}{|c|c|c|c|c|}
\hline & $\begin{array}{c}\text { Breccia zone } \\
\text { (North) }\end{array}$ & $\begin{array}{l}\text { Breccia zone } \\
\text { (South) }\end{array}$ & $\begin{array}{c}\text { Breccia zone } \\
\text { (vein) }\end{array}$ & $\begin{array}{l}\text { Host Gabbro } \\
\text { Anorthosite }\end{array}$ \\
\hline \multicolumn{5}{|l|}{ Main sulfides } \\
\hline chalcopyrite & 0 & 0 & - & $\bullet$ \\
\hline pyrrhotite & $\bullet$ & - & - & $\bullet$ \\
\hline pentlandite & $\bullet$ & - & 0 & $\bullet$ \\
\hline cobaltite-gersdorffite & $\bullet$ & $\bullet$ & & - \\
\hline millerite & 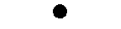 & & & \\
\hline pyrite & $\bullet$ & & $\bullet$ & - \\
\hline \multicolumn{5}{|l|}{ Subordinate sulfides } \\
\hline $\begin{array}{l}\text { violarite } \\
\text { mackinawite } \\
\text { cubanite }\end{array}$ & $\bullet$ & $\bullet$ & 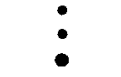 & \\
\hline bomite & $\bullet$ & & & \\
\hline ullmannite & $\bullet$ & $\bullet$ & & $\bullet$ \\
\hline \multicolumn{5}{|l|}{ Rare sulfides } \\
\hline heazlewoodite & $\bullet$ & & & \\
\hline orcelite & - & & & \\
\hline maucherite & $\bullet$ & & & \\
\hline nickeline & $\bullet$ & & & \\
\hline molybdenite & & & & $\bullet$ \\
\hline galena & - & - & & \\
\hline
\end{tabular}

TABLE 3. PGE, AU AND Re CONTENT OF SELECTED SAMPLES FROM THE TWO MINERALIZED ENVIRONMENTS, BAULA COMPLEX, INDIA

\begin{tabular}{|c|c|c|c|c|c|c|c|c|}
\hline $\mathrm{ppb}$ & Os & Ir & Ru & Rh & $\mathrm{Pt}$ & $\mathrm{Pd}$ & $\mathrm{Au}$ & $\mathrm{Re}$ \\
\hline \multicolumn{9}{|l|}{ Type 1 Magmatic } \\
\hline OBG1 & 226 & 636 & 1670 & 2210 & 5240 & 770 & 15 & 20 \\
\hline OBG1R & 143 & 485 & 1220 & 1800 & 1100 & 173 & 2 & 13 \\
\hline BN40 & 355 & 1250 & 3550 & 3830 & 9700 & 1720 & 20 & 32 \\
\hline \multicolumn{9}{|c|}{ Type $2 A$ Hydrothermal, sulfide-bearing } \\
\hline FGH1 215 & 4 & 6.9 & 37 & 22 & 523 & 1790 & 229 & 2 \\
\hline FGH1 228 & 9 & 19.1 & 183 & 40 & 425 & 1630 & 130 & 1 \\
\hline FGH1 234 & 9 & 19.3 & 205 & 43 & 319 & 2270 & 73 & 1 \\
\hline FGH3 64 & 14 & 34 & 240 & 91 & 1410 & 2840 & 95 & 2 \\
\hline FGH3 79 & 5 & 10 & 99 & 16 & 261 & 1530 & 62 & $<1$ \\
\hline FGH5 52 & 3 & 11.5 & 89 & 20 & 421 & 4170 & 127 & $<1$ \\
\hline FGH5 75 & 13 & 24.5 & 192 & 49 & 1190 & 3690 & 224 & 2 \\
\hline FGH5 94 & 28 & 42.5 & 341 & 91 & 1210 & 2440 & 151 & 3 \\
\hline BLR96 & 30 & 113 & 188 & 1170 & 1650 & 25800 & 3250 & 28 \\
\hline FGH4 2 & 7 & 53.6 & 249 & 280 & 4350 & 3070 & 149 & $<1$ \\
\hline FGH4 59 & 6 & 16.4 & 128 & 37 & 516 & 2300 & 70 & $<1$ \\
\hline BLR42 & 22 & 27.1 & 161 & 89 & 1670 & 6090 & 630 & 8 \\
\hline \multicolumn{9}{|c|}{ Type 2B Hydrothermal, sulfide-free } \\
\hline FGH4 1 & 7 & 17.9 & 116 & 72 & 1300 & 1000 & 225 & $<1$ \\
\hline FGH4 3 & 9 & 44.7 & 215 & 265 & 3630 & 2120 & 174 & $<1$ \\
\hline FGH4 4 & 6 & 30.9 & 149 & 177 & 2880 & 1850 & 202 & $<1$ \\
\hline FGH4 5 & 7 & 24.3 & 107 & 117 & 1840 & 1980 & 351 & $<1$ \\
\hline FGH5 91 & 16 & 33.8 & 207 & 85 & 1000 & 1210 & 92 & 2 \\
\hline FGH5 92 & 30 & 78.7 & 429 & 203 & 2460 & 2200 & 46 & 4 \\
\hline $\mathrm{FSH} 142$ & 15 & 39.5 & 201 & 161 & 1230 & 1450 & 55 & 2 \\
\hline $\mathrm{FSH} 169$ & 29 & 56.5 & 346 & 212 & 1390 & 1670 & 84 & 3 \\
\hline FSH1 72 & 34 & 54.8 & 296 & 199 & 1420 & 1790 & 71 & 3 \\
\hline
\end{tabular}

that are generally included in plagioclase. This process has slightly affected the chromite composition and in places has transformed the chromite into ferrian chromite (Augé et al., in prep).

Platinum-group minerals occur mainly as inclusions in the magmatic silicates; only in rare cases are they included in chromite nodules.

Type $2 A$

Type $2 \mathrm{~A}$ is much more widespread than Type 1 because it occurs within the matrix of the extensive breccia zone (Mondal et al. 2001). Several variants are developed, the most common being the hydrothermally altered matrix, which is systematically PGE-mineralized and contains ferrian chromite with interstitial BMS (Tables 1,2). Typically, material from this facies assays 7.6 to 12.2 wt.\% Cr, with an average of 50 vol.\% ferrian chromite and $0.2 \%$ to 4.5 wt. $\% \mathrm{~S}$, the sulfides forming 5 to 10 vol. $\%$ of the rock. Hand specimens show 1.8-7.1 ppm Pd, 0.7-2.3 ppm Pt, a Pt/Pd ratio below 1 (between 0.22 and 0.77 ) and good correlation between $\mathrm{Pt}$ and $\mathrm{Pd}$ (for some samples). Correlations involving $\mathrm{Cu}-\mathrm{Pd}$ (Fig. 5) and $\mathrm{Pd}-\mathrm{S}$ indicate a close association between the PGE and BMS mineralization, and a similar close association between the platinum-group and base-metal sulfide minerals confirms this. The gold content varies between $130 \mathrm{ppb}$ and $575 \mathrm{ppb}$, and increases with increasing PGE content of the rock. Mondal et al. (2001) also reported high Ag values, up to $6.6 \mathrm{ppm}$. 
Type $2 \mathrm{~A}$ also includes hydrothermally altered gabbro (breccia matrix) with disseminated base-metal sulfides and no ferrian chromite, where PGE mineralization contains 1.1-7.1 ppm Pd, 0.3-1.6 ppm Pt, and Pt/Pd values of less than 0.5. Close correlations for $\mathrm{Pt}-\mathrm{Pd}, \mathrm{Cu}-$ $\mathrm{Pd}$ and Pd-S suggest that the PGE and BMS mineralization are related. Gold values increase with PGE content.

The association of massive BMS with ferrian chromite, assaying 7.4 to 9.8 wt.\% $\mathrm{Cr}$ and 6 wt.\% S, also seems related to Type $2 \mathrm{~A}$. The Pd values are extremely high (up to $25.9 \mathrm{ppm}$ ), but $\mathrm{Pt}$ values are relatively low $(0.5-2.0 \mathrm{ppm})$ resulting in very low $\mathrm{Pt} / \mathrm{Pd}$ values $(<0.1)$, and $\mathrm{Au}$ concentrations are high at 2 to $3.3 \mathrm{ppm}$. It should be noted, however, that one sample of massive BMS without ferrian chromite gave much lower PGE and Au values (2910 ppb Pd, 510 ppb Pt, and $57 \mathrm{ppb} \mathrm{Au}$ ).

A chondrite-normalized PGE pattern for selected samples of Type $2 \mathrm{~A}$ is presented in Figure 4 (representative PGE data are given Table 3 ) and shows a positive and constant slope from $\mathrm{Os}$ to $\mathrm{Pd}$, and a negative slope from Pd to Au.

In Type-2A mineralization, the three main types of BMS assemblage (Table 2) consist of varying amounts of chalcopyrite (main sulfide), pyrrhotite, pentlandite, violarite, millerite, pyrite, and minerals belonging to the cobaltite-gersdorffite solid-solution series, as reported

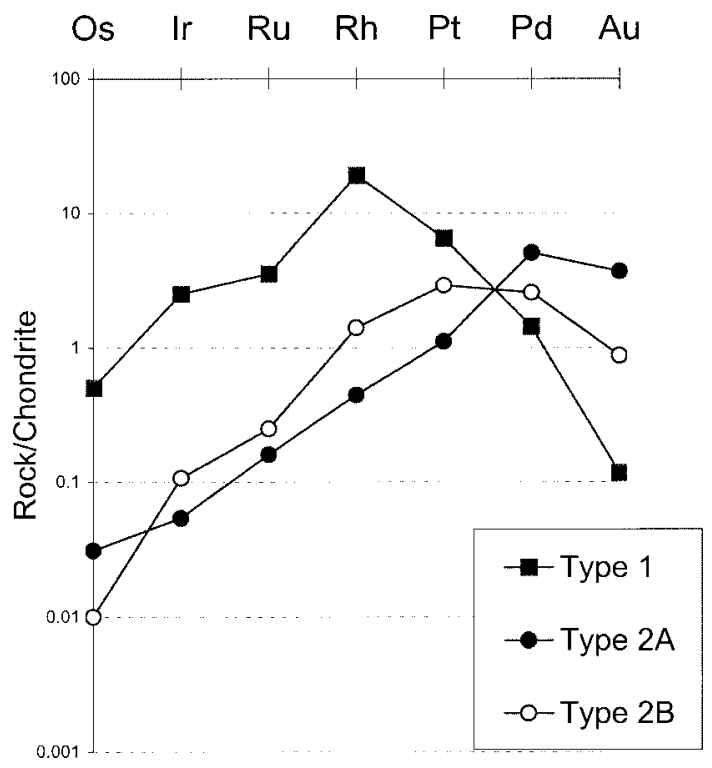

FIG. 4. Chondrite-normalized platinum-group-element contents for the magmatic (type 1) and hydrothermal (type 2) mineralization in the Baula Complex. Chondrite values used for normalization are Os 700, Ir 500, Ru 1000, Rh 200, Pt 1500, Pd 1200, and Au 170 ppb. by Mondal et al. (2001). These minerals are associated with less common and rare minerals that include maucherite $\left(\mathrm{Ni}_{11} \mathrm{As}_{8}\right)$, nickeline (NiAs), heazlewoodite $\left(\mathrm{Ni}_{3} \mathrm{~S}_{2}\right)$, cubanite, bornite, mackinawite, $\mathrm{Ag}-\mathrm{Au}$ alloy, ullmannite (NiSbS), galena, and orcelite $\left(\mathrm{Ni}_{5-x} \mathrm{As}_{2}\right)$. They are restricted to the breccia matrix and are absent from the Bangur Gabbro. Note, however, that traces of base-metal sulfides are identified the host Gabbro-Anorthosite Unit (Table 2).

The BMS minerals generally occur interstitially to grains of hydrothermal silicates and have disseminated and net textures. Small inclusions commonly occur within ferrian chromite crystals, apparently replacing rutile-ilmenite exsolution-induced assemblages, and, in some cases, ferrian chromite crystals appear partly digested by the sulfide assemblage. Rare millimetric BMS veinlets cut and brecciate grains of ferrian chromite.

\section{Type $2 B$}

Type $2 \mathrm{~B}$ is also restricted to the ferrian-chromiteenriched matrix of the breccia zone, and is distinguished from Type $2 \mathrm{~A}$ by a lack of base-metal sulfides (Table1) and different $\mathrm{Pt} / \mathrm{Pd}$ values. Typically, it contains 6.6 to 17.0 wt. $\% \mathrm{Cr},<0.05$ wt. \% S, and varies in character from disseminated ferrian chromite in a silicate matrix of amphiboles and chlorite (altered pyroxenes) to massive ferrian chromite. Typically, the textures are reminiscent of the "occluded silicates" texture of chromitite (where nodules of silicates are cemented by ferrian chromite crystals). Type 2B is Pt-rich (1.2-6.3 ppm Pt, 0.4-3.7 ppm Pd), with Pt/Pd between 2 and 3, characterized by low gold values (around $50 \mathrm{ppb} \mathrm{Au}$ ) and is not systematically PGE-bearing.

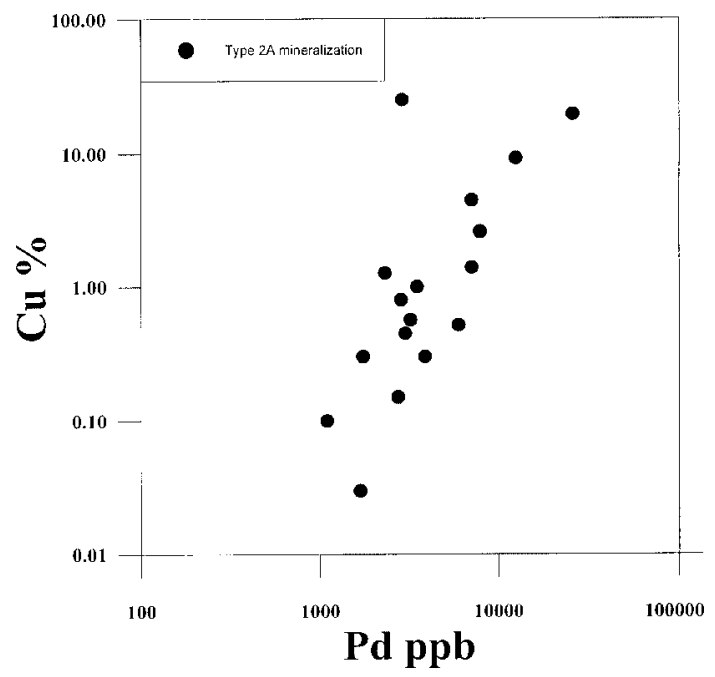

FIG. 5. Pd-Cu correlation diagram for the type-2A mineralization. 
A chondrite-normalized PGE pattern for a selected sample of this type, presented in Figure 4 (representative PGE data are given Table 3), shows a positive slope from $\mathrm{Os}$ to $\mathrm{Pt}$, and a shallow negative slope from $\mathrm{Pt}$ to $\mathrm{Au}$.

Table 1 summarizes the main characteristics of the PGE mineralization. It shows that Pd typically dominates the PGE in the sulfide-bearing rocks (type 2A), and that the PGE in the sulfide-free rocks (types 1 and 2B) are typically Pt-rich. Table 2 shows the main basemetal sulfide mineral assemblages found in type-2B mineralization and in samples of the host Gabbro-Anorthosite Unit.

\section{Base-metal and platinum-group minerals}

Representative base-metal sulfide grains and some 300 platinum-group mineral grains from the various types of mineralization were analyzed. In most cases, several analyses were made on mineral grains and those analytical compositions with totals close to $100 \%$ and a satisfactory structural formula were selected as representative (Tables 4 to 11), except in cases of heterogeneous compositions.

\section{Base-Metal Sulfides}

Base-metal sulfides in the Baula Complex are characteristic of Type-2A mineralization. Of the three types of assemblage (Table 2) observed, the first is preferentially located in the northern part of the Breccia zone and the second in its southern part; the third seems to be restricted to veinlets in the Breccia zone. This spatial distribution is not without exceptions, and both northern and southern types may coexist in a given outcrop. Photomicrographs of the various types of mineral assemblage are shown in Figure 6, and their representative compositions are given in Tables 4, 5 and 6.

\section{$\mathrm{Fe}-\mathrm{Cu}$ and $\mathrm{Fe}$ sulfides}

Chalcopyrite is by far the dominant sulfide (Fig. 6B), and its composition is close to $\mathrm{CuFeS}_{2}$ with no significant amounts of other detectable elements (Table 4). The chalcopyrite frequently contains pyrrhotite-pentlandite inclusions in strings that suggest exsolution. Bornite is present in a few samples only. Cubanite (Table 4) was observed in pentlandite-pyrrhotite-rich veinlets, together with small amounts of chalcopyrite, as well as rare lamellae in samples of nearly massive chalcopyrite (Fig. 6C).

Two types of pyrrhotite, characterized by high and low reflectance, were reported by Mondal et al. (2001), but such differences were not observed in the current study. Pyrrhotite is present in all the samples, although in lower abundance than chalcopyrite. It occurrs mostly with pentlandite, which in some cases forms flame-like exsolution-induced domains (Fig. 6A). The pyrrhotite is replaced locally by pyrite or magnetite; it characteristically has an Fe deficiency up to $20 \%$ of the stoichiometric quantity, and shows traces of $\mathrm{Ni}(<0.6 \mathrm{wt} . \%)$. Its chemical composition is relatively constant whatever the location of the samples (Table 4).

Pyrite is not abundant, and restricted mainly to millerite-pyrite assemblages (Figs. 6D, E). Small crystals, between 10 and $100 \mu \mathrm{m}$, are present locally in pentlandite and pyrrhotite. Where associated with millerite, the pyrite crystals are euhedral, well developed (up to 300 $\mu \mathrm{m}$ in size) and commonly host micrometric inclusions of chalcopyrite. They are characterized by 0 to $5.4 \mathrm{wt} . \%$ Co, 0 to 2.32 wt.\% Ni and locally up to 1.65 wt. $\%$ As, as shown in Table 4.

\section{Ni-bearing phases}

Pentlandite, millerite and violarite are the main Nibearing phases, with heazlewoodite and associated orcelite and ullmannite present in a few samples as accessory minerals. Pentlandite is dominant in a few samples, but generally is much less plentiful. It occurs as euhedral crystals attached to pyrrhotite or, more rarely, as flames in pyrrhotite (Fig. 6A). The atomic ratio $\mathrm{Ni} / \mathrm{Fe}$ ranges between 0.87 to 1.60 , and the Co content is lower than 1 at.\% except in chalcopyrite - cubanite pentlandite - pyrrhotite assemblages, in which the pentlandite has a higher $\mathrm{Ni} / \mathrm{Fe}$ value and Co content $(<2.5$ wt.\%, Table 5).

Violarite is present in nearly all samples, partially or totally replacing pentlandite crystals (Fig. 6F). Different stages of replacement can be recognized, ranging from micrometric specks of violarite developed throughout the pentlandite grains, to violarite wires disposed along the octahedral cleavage planes, and finally to almost complete replacement of pentlandite grains that remain visible as relics in violarite masses. Violarite also appears as fine lamellar intergrowths with pentlandite and millerite, and replaces pyrrhotite rims on pentlandite. The atomic ratio $\mathrm{Ni} / \mathrm{Fe}$ of violarite ranges between 0.91 and 1.70 and, in most cases, is similar to that of pentlandite from which it is derived. The Co content is also conserved during replacement, except in a few cases where high values $(<6.1$ at. $\%)$ are recorded (Table 5).

Millerite (NiS) was observed only in samples where chalcopyrite is associated with bornite. It occurs as large anhedral crystals commonly associated with euhedral crystals of pyrite or as lamellar crystals intimately associated with violarite and pentlandite (Fig. 6D). It contains significant $\mathrm{Fe}(<3.4$ wt.\%) and $\mathrm{Co}(<1.4$ wt.\%) (Table 6).

Rare assemblages include a heazlewoodite - orcelite - chalcopyrite - cobaltite - gersdorffite veinlet, and common ullmannite (NiSbS) crystals isolated in silicates and included in chalcopyrite. Representative compositions are given in Table 6. 


\section{As-(Sb-)bearing phases}

Arsenide phases of the cobaltite-gersdorffite series are commonly found within sulfides, whereas maucherite, nickeline and orcelite are rare. Cobaltite- gersdorffite crystals are present in nearly all the samples except those in which pentlandite is dominant. Cobaltite-gersdorffite appears mainly as euhedral crystals 10$300 \mu \mathrm{m}$ across within chalcopyrite and pyrrhotite or interstitial to silicate minerals (Fig. 6A). In one sample,
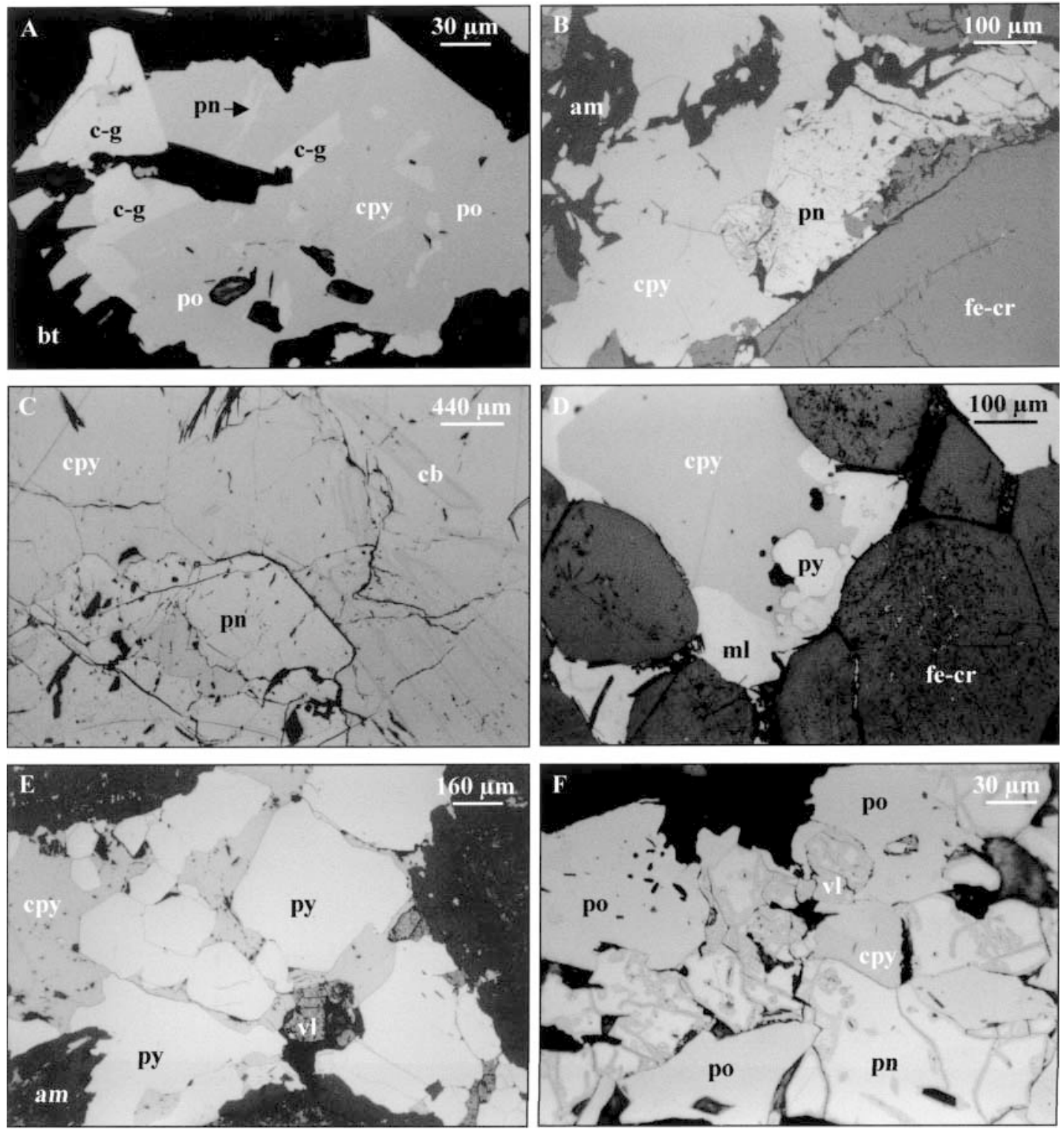

FIG. 6. Base-metal-sulfide images (non-polarized reflected light). A. Cobaltite-gersdorffite crystals included in pyrrhotite and chalcopyrite. The gangue minerals are represented by hydrothermal biotite (sample BLR45). B. Pentlandite in chalcopyrite moulding hydrothermal amphibole (sample BLR41). C. Cubanite exsolution-induced blebs in chalcopyrite (sample BLR 95). D. Millerite associated with chalcopyrite and euhedral crystals of pyrite (sample BLR88). E. Large euhedral crystals of pyrite included in chalcopyrite (sample BLR82). F. Pentlandite partly replaced by violarite with chalcopyrite and pyrrhotite (sample BLR42). Symbols: cpy: chalcopyrite; py: pyrite; po: pyrrhotite; pn: pentlandite; c-g: cobaltite-gersdorffite; vl: violarite; ml: millerite; fe-cr: ferrian chromite; bt: biotite; am: amphibole. 


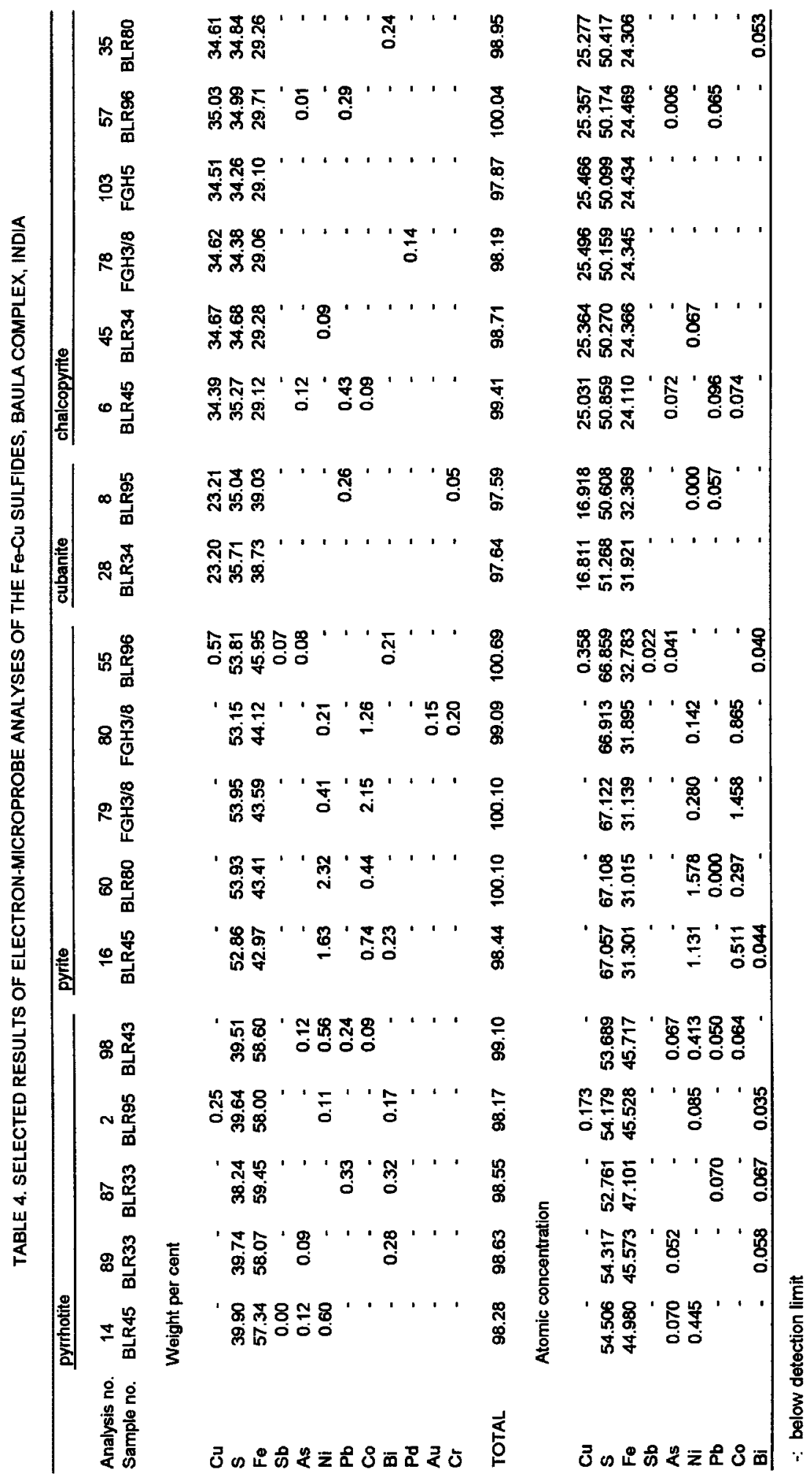


TABLE 5. SELECTED RESULTS OF ELECTRON-MICROPROBE ANALYSES OF PENTLANDITE AND VIOLARITE, BAULA COMPLEX, INDIA

\begin{tabular}{|c|c|c|c|c|c|c|c|c|c|c|c|c|c|c|c|c|c|c|c|}
\hline \multirow[b]{2}{*}{$\begin{array}{l}\text { Analysis } \\
\text { Sample } n\end{array}$} & \multicolumn{9}{|c|}{ pentlandite } & \multicolumn{10}{|l|}{ violaríe } \\
\hline & $\begin{array}{c}19 \\
\text { BLR45 } \\
\text { Weight }\end{array}$ & $\begin{array}{c}49 \\
\text { BLR50 } \\
\text { per cent }\end{array}$ & $\begin{array}{c}66 \\
\text { BLR80 }\end{array}$ & $\begin{array}{c}84 \\
\text { BLR33 }\end{array}$ & $\begin{array}{c}98 \\
\text { BN83 }\end{array}$ & BLRُR95 & $\stackrel{17}{\text { BLR95 }}$ & $\begin{array}{c}37 \\
\text { BLR44 }\end{array}$ & $\begin{array}{c}179 \\
\text { FGH3 }\end{array}$ & $\begin{array}{c}47 \\
\text { BLR50 }\end{array}$ & $\stackrel{48}{\text { BLR50 }}$ & $\begin{array}{c}64 \\
\text { BLR80 }\end{array}$ & $\stackrel{61}{\text { BLR80 }}$ & BLR95 & $\begin{array}{c}75 \\
\text { BN43 }\end{array}$ & $\begin{array}{c}76 \\
\text { BN43 }\end{array}$ & $\begin{array}{c}89 \\
\text { BN85 }\end{array}$ & $\begin{array}{c}93 \\
\text { BN85 }\end{array}$ & $\begin{array}{c}164 \\
\text { FGH3 }\end{array}$ \\
\hline $\begin{array}{l}\mathrm{Cu} \\
\mathrm{S} \\
\mathrm{Fe} \\
\mathrm{Sb} \\
\mathrm{As} \\
\mathrm{Ni} \\
\mathrm{Pb} \\
\mathrm{Co} \\
\mathrm{Pt} \\
\mathrm{Pd} \\
\mathrm{Cr} \\
\mathrm{Ag} \\
\mathrm{Rh}\end{array}$ & $\begin{array}{r}0.17 \\
33.37 \\
28.26 \\
- \\
36.29 \\
0.21 \\
1.10 \\
- \\
- \\
- \\
- \\
-\end{array}$ & $\begin{array}{r}0.27 \\
33.20 \\
26.51 \\
- \\
38.86 \\
0.17 \\
- \\
- \\
- \\
-\end{array}$ & $\begin{array}{r}33.48 \\
26.42 \\
- \\
39.02 \\
0.00 \\
0.31 \\
- \\
0.06 \\
0.19 \\
-\end{array}$ & $\begin{array}{r}0.12 \\
33.82 \\
30.56 \\
53.48 \\
- \\
1.89 \\
- \\
- \\
- \\
-\end{array}$ & $\begin{array}{r}33.94 \\
27.03 \\
- \\
36.00 \\
1.39 \\
- \\
- \\
-\end{array}$ & $\begin{array}{r}33.98 \\
31.60 \\
32.34 \\
1.15 \\
- \\
- \\
-\end{array}$ & $\begin{array}{r}33.97 \\
31.76 \\
- \\
- \\
32.00 \\
0.18 \\
1.09\end{array}$ & $\begin{array}{r}32.95 \\
28.43 \\
- \\
36.77 \\
0.22 \\
0.61 \\
- \\
0.05 \\
- \\
-\end{array}$ & $\begin{array}{r}33.42 \\
25.21 \\
- \\
40.04 \\
0.04 \\
0.64 \\
0.09 \\
\text { nd } \\
0.04\end{array}$ & $\begin{array}{r}0.16 \\
42.70 \\
24.27 \\
- \\
31.79 \\
0.23 \\
- \\
- \\
-\end{array}$ & $\begin{array}{r}0.28 \\
42.55 \\
23.89 \\
- \\
30.55 \\
- \\
0.21 \\
- \\
-\end{array}$ & $\begin{array}{r}42.46 \\
20.67 \\
-0 \\
0.08 \\
34.45 \\
2.61 \\
- \\
- \\
-\end{array}$ & $\begin{array}{r}41.47 \\
9.21 \\
- \\
46.70 \\
0.13 \\
- \\
- \\
0.20 \\
0.11\end{array}$ & $\begin{array}{r}0.20 \\
39.19 \\
28.78 \\
- \\
0.13 \\
27.57 \\
0.22 \\
1.14 \\
- \\
0.17 \\
0.20\end{array}$ & $\begin{array}{r}0.23 \\
42.57 \\
18.23 \\
- \\
36.56 \\
0.31 \\
1.00 \\
- \\
0 \\
0.17 \\
- \\
-\end{array}$ & $\begin{array}{r}40.45 \\
14.76 \\
0.12 \\
0.70 \\
38.65 \\
0.28 \\
1.75 \\
- \\
0.13 \\
\end{array}$ & $\begin{array}{r}42.16 \\
18.27 \\
0.03 \\
30.46 \\
0.28 \\
8.30 \\
- \\
0.65 \\
-\end{array}$ & $\begin{array}{r}41.76 \\
20.69 \\
- \\
31.91 \\
3.70 \\
- \\
- \\
-\end{array}$ & $\begin{array}{r}41.89 \\
19.08 \\
- \\
0.05 \\
31.34 \\
0.20 \\
3.76 \\
0.58 \\
0.15 \\
0.03 \\
\text { nd }\end{array}$ \\
\hline TOTAL & $\begin{array}{r}99.41 \\
\text { Atomic }\end{array}$ & $\begin{array}{l}99.01 \\
\text { concentr }\end{array}$ & $\begin{array}{c}99.47 \\
\text { tration }\end{array}$ & 99.87 & 98.35 & 99.07 & 98.99 & 99.02 & 99.48 & 99.15 & 97.48 & 100.27 & 97.82 & 97.59 & 99.06 & 96.83 & 100.13 & 98.08 & 97.08 \\
\hline $\begin{array}{l}\mathrm{Cu} \\
\mathrm{S} \\
\mathrm{Fe} \\
\mathrm{Sb} \\
\mathrm{As} \\
\mathrm{Ni} \\
\mathrm{Pb} \\
\mathrm{Co} \\
\mathrm{Pt} \\
\mathrm{Pd} \\
\mathrm{Cr} \\
\mathrm{Ag} \\
\mathrm{Rh}\end{array}$ & $\begin{array}{r}0.122 \\
47.656 \\
23.171 \\
0.000 \\
0.00 \\
28.319 \\
0.046 \\
0.855 \\
\end{array}$ & $\begin{array}{r}0.194 \\
47.602 \\
21.823 \\
= \\
30.441 \\
0.134 \\
- \\
= \\
-\end{array}$ & $\begin{array}{r}47.735 \\
21.624 \\
= \\
30.397 \\
0.244 \\
- \\
0.048 \\
0.078\end{array}$ & $\begin{array}{r}0.084 \\
47.839 \\
24.826 \\
- \\
25.878 \\
- \\
-4.458 \\
- \\
- \\
- \\
-\end{array}$ & $\begin{array}{r}48.566 \\
22.206 \\
28.146 \\
- \\
1.082 \\
- \\
- \\
-\end{array}$ & $\begin{array}{r}48.253 \\
25.762 \\
- \\
25.097 \\
0.889 \\
- \\
- \\
-\end{array}$ & $\begin{array}{r}24.868 \\
-0.039 \\
0.844 \\
-\quad- \\
- \\
-\end{array}$ & $\begin{array}{r}47.229 \\
23.400 \\
- \\
28.801 \\
0.048 \\
0.477 \\
- \\
0.045 \\
-\end{array}$ & $\begin{array}{r}47.600 \\
20.620 \\
0.000 \\
31.150 \\
0.010 \\
0.490 \\
0.040 \\
- \\
-\end{array}$ & $\begin{array}{r}0.111 \\
57.597 \\
18.797 \\
- \\
23.437 \\
0.170\end{array}$ & $\begin{array}{r}0.196 \\
58.229 \\
18.773 \\
- \\
22.845 \\
0.153 \\
- \\
-\end{array}$ & $\begin{array}{r}56.940 \\
15.914 \\
0 \\
0.046 \\
25.241 \\
1.905\end{array}$ & $\begin{array}{r}57.379 \\
7.317 \\
0.002 \\
35.304 \\
0.097 \\
- \\
- \\
-0.082 \\
0.049\end{array}$ & $\begin{array}{r}0.139 \\
54.892 \\
23.143 \\
0.078 \\
21.099 \\
0.049 \\
0.867 \\
0.072 \\
0.082 \\
-\end{array}$ & $\begin{array}{r}0.154 \\
57.875 \\
14.229 \\
0.000 \\
27.153 \\
0.065 \\
0.743 \\
- \\
0.139 \\
-\end{array}$ & $\begin{array}{r}56.732 \\
11.889 \\
0.044 \\
0.418 \\
29.627 \\
0.062 \\
1.334 \\
- \\
0.109 \\
-\end{array}$ & $\begin{array}{r}56.815 \\
14.136 \\
0.014 \\
22.429 \\
0.058 \\
6.084 \\
\\
0.536 \\
\end{array}$ & $\begin{array}{r}57.127 \\
16.257 \\
0.000 \\
23.858 \\
2.758 \\
- \\
= \\
-\end{array}$ & $\begin{array}{r}57.940 \\
15.150 \\
0.030 \\
23.670 \\
0.040 \\
2.830 \\
0.130 \\
0.060 \\
0.020\end{array}$ \\
\hline
\end{tabular}

they are partially replaced by a pentlandite-pyrrhotite assemblage. Inclusions of laurite, sudburyite and sperrylite are commonly observed in the core of cobaltitegersdorffite crystals. For most of the arsenide crystals, $\mathrm{Ni}$ values are between 0 and $10 \mathrm{wt} . \%$, but two samples show values between 10 and 25 wt.\%. Significant Pd values $(<2.5$ wt. $\%$ ) were recorded in some crystals, but the analyses could not be related optically to PGM inclusions (Table 6). Most of the compositions plot in the $300^{\circ}-500^{\circ} \mathrm{C}$ region of immiscibility in the system CoAsS-NiAsS-FeAsS (Klemm 1965), except those obtained on Ni-rich crystals, which are restricted to the $400-500^{\circ} \mathrm{C}$ immiscibility region (Fig. 7).

Maucherite and nickeline were identified in only one sample; both phases are associated with traces of cobaltite-gersdorffite and violarite (Table 6).

\section{Platinum-Group Minerals}

\section{Mineral descriptions}

Platinum-group minerals in the Baula mineralization are dominated by Pd and Pt phases that reflect the high whole-rock content of platinum-group elements. The PGM are characterized by a small grain-size, averaging 5-10 $\mu \mathrm{m}$. Grains smaller than $2 \mu \mathrm{m}$ are common, although larger grains can be up to $70 \times 35 \mu \mathrm{m}$. A few very large grains $(260 \times 150 \mu \mathrm{m})$ were observed in alluvial concentrates. Various morphologies of the PGM and a number of different mineral associations are illustrated in Figures 8 and 9.
The main types of mineralization are characterized by specific assemblages of PGM and modes of occurrence. In Type-1 mineralization, the PGM are included in magmatic silicates, such as plagioclase or pyroxene and their altered equivalents. In rare cases, they are also found in chromitite nodules. In both cases, they tend to form euhedral to subhedral crystals. Although it lacks base-metal sulfides, Type 1 contains abundant PGE sulfides that include laurite, braggite, malanite and its $\mathrm{Ni}$ rich equivalent. It also contains isoferroplatinum; in fact, isoferroplatinum, malanite and its $\mathrm{Ni}$-rich equivalent are restricted to Type 1, whereas sperrylite and hollingworthite occurs in all three types. The only Pd minerals in Type 1 are rare mertieite-II and potarite (Table 1).

Type-2A PGM have more complex modes of occurrence, with discrete grains occurring a) as clusters in hydrous silicates (Fig. 8B), accompanying BMS trails (Figs. 8E, F), or adjacent to disseminated BMS (Fig. 9A), b) within ferrian chromite (Figs. 8C, D), c) within BMS in silicates, and d) within or adjacent to BMS in ferrian chromite.

The crystals may be euhedral (Fig. 8A) or, more commonly, roundish, as where found in silicates. In some instances where they are enclosed within ferrian chromite, their habit suggests exsolution or the infilling of negative crystals (Figs. 8C, D). In silicates, they are invariably in hydrous silicates or in late fractures (Figs. $8 \mathrm{~F}, 9 \mathrm{~B}$ ), and there are no instances in which the PGM are associated with magmatic minerals. The PGM commonly form composite grains (two or more PGM), or one or more PGM associated with BMS (Figs. 9C, D). 


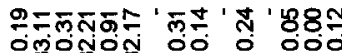

'

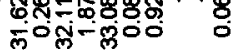

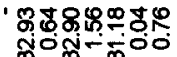

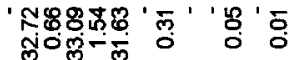

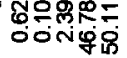

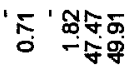

' 응 ' ㅉํำ

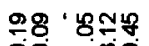

ơ -io

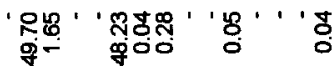

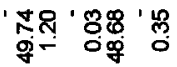

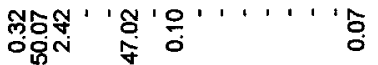

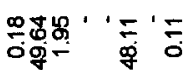

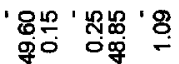

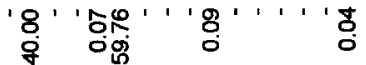

'苍' '

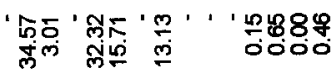

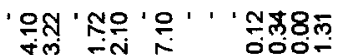

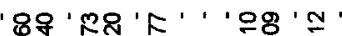

幽 迎

' 녕 ' 으요용'

सुलं ब्लिण्त

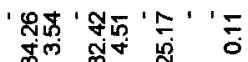

ला ल्ले ल

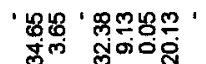

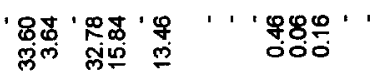

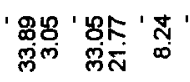

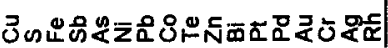


They can also form concretion-like textures with BMS (Fig. 9F). The textural relationships between the PGM and the BMS indicate that both were introduced during the same event.

Type-2A assemblages contain the greatest variety of PGM, dominated by Pd antimonide and phases of the system Pd-Te-Sb-Bi (Table 1). Sudburyite is the most abundant Pd mineral, coexisting with mertieite-II $\mathrm{Pd}_{8}(\mathrm{Sb}, \mathrm{As})_{3}$ and merenskyite $\mathrm{PdTe}_{2}$ (which is restricted to type 2A). Five other Pd minerals were identified, all of which belong to the system $\mathrm{Pd}-\mathrm{Ag}-\mathrm{Te}-\mathrm{Bi}-\mathrm{Sb}$. They are either new minerals or uncommon end-members of known species. Laurite and hollingworthite are rare, and sperrylite is the only Pt-mineral in type 2A. Gold-silver alloy is present, either as rare and small inclusions $(2-4 \mu \mathrm{m})$ in pyrrhotite or as larger inclusions $(<35 \mu \mathrm{m})$ in ferrian chromite.

The PGM in type-2B assemblages show textural characteristics similar to those in type- 1 assemblages, except that there are no base-metal sulfides. The assemblage of PGM is different, with geversite restricted to type-2B assemblages, where it commonly forms composite grains with sperrylite. Both type-2A and type-1 assemblages contain braggite (Table 1).
Chromite from the chromitite layer in the peridotite unit contains very small osmium inclusions (Table 1) that, in some cases, are adjacent to silicate inclusions. This mode of PGM occurrence is common in chromitites of whatever origin (stratiform or ophiolite complexes).

Mondal \& Baidya (1997), and Mondal et al. (2001) reported the additional presence of palladian-bismuthian melonite $(\mathrm{Ni}, \mathrm{Pd})(\mathrm{Te}, \mathrm{Bi})_{2}$, michenerite and sudburyite in sulfide-rich samples and Rh-rich irarsite within cobaltite-gersdorffite grains from the Baula Complex.

\section{Isoferroplatinum}

Isoferroplatinum is restricted to type- 1 assemblages, where it forms abundant euhedral to subhedral crystals (up to $25 \times 30 \mu \mathrm{m}$ ) included in pyroxene and plagioclase. It is essentially homogeneous in composition, close to the ideal $\mathrm{Pt}_{3} \mathrm{Fe}$ end-member, although some grains contain $<1.8$ wt. $\% \mathrm{Cu},<2.1$ wt.\% $\mathrm{Pd}$, and restricted substitution of $\mathrm{Pt}$ for $\mathrm{Fe}$ (Table 7). The average structural formula derived from results of 30 analyses is $\left(\mathrm{Pt}_{2.83} \mathrm{Cu}_{0.10} \mathrm{Rh}_{0.05} \mathrm{Ni}_{0.03} \mathrm{Pd}_{0.02}\right)_{\Sigma 3.03} \mathrm{Fe}_{0.97}$.

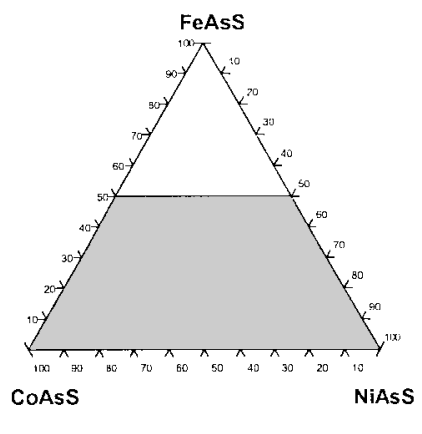

\section{FeAsS}
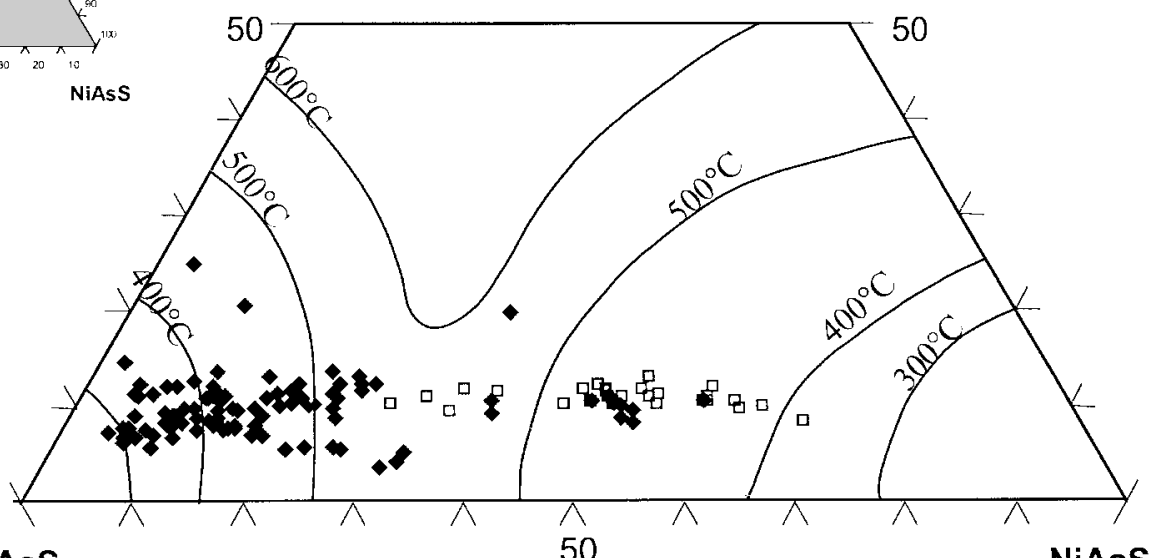

CoAsS

FIG. 7. Plot of cobaltite-gersdorffite (atomic concentration). Solvus lines at $300^{\circ}, 400^{\circ}, 500^{\circ}$ and $600^{\circ} \mathrm{C}$ are taken from Klemm (1965). Open squares correspond to the values obtained on one sample (BLR45), black diamonds to values obtained on 11 samples of the mineralization. 

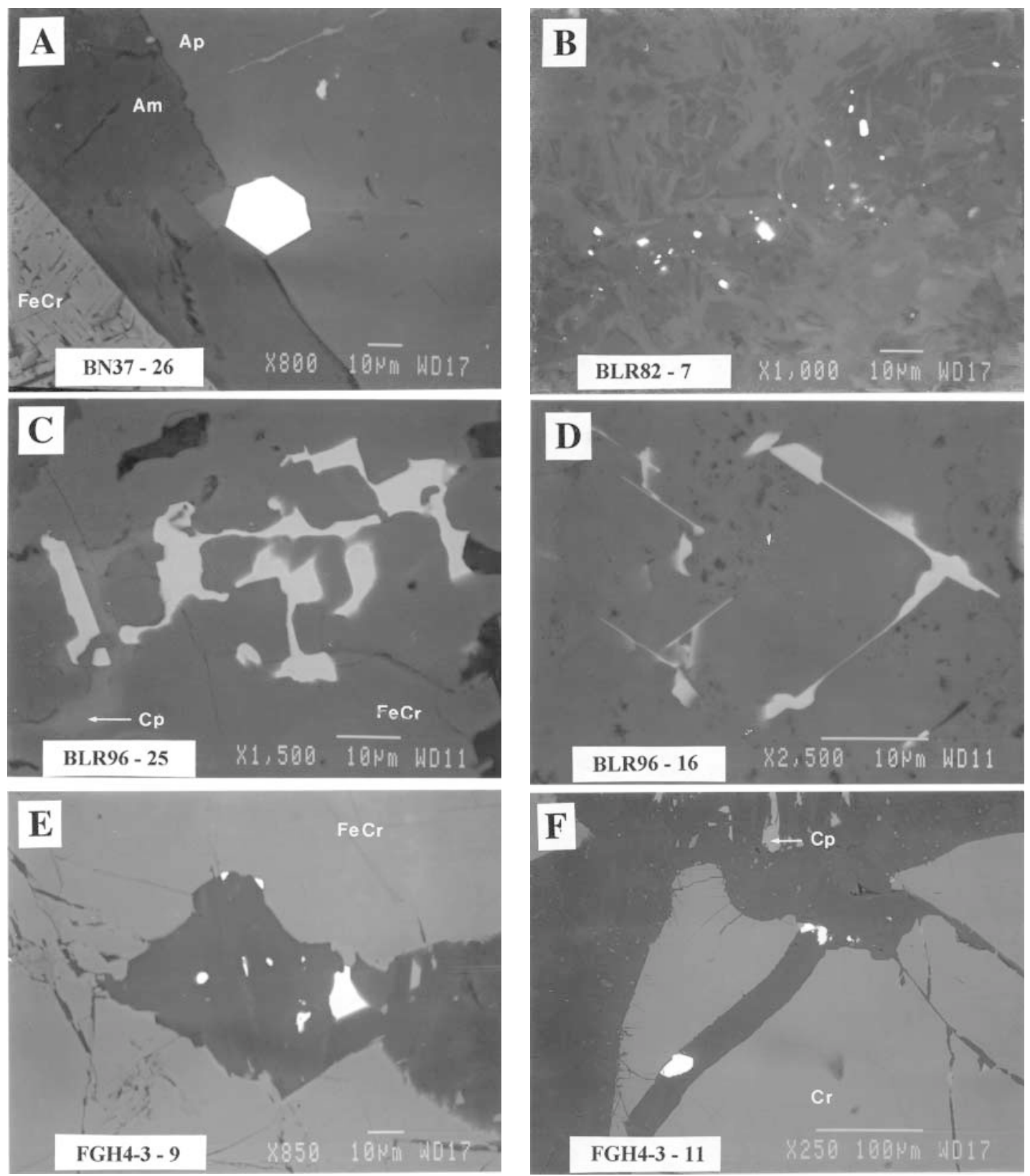

FIG. 8. Scanning electron microscope images of PGM. A. Euhedral crystal of sperrylite (white) at the grain boundary between apatite (Ap) and amphibole (Am). Bottom left: ferrian chromite ( $\mathrm{FeCr}$ ). B. Cluster of several grains of sudburyite (white) in a silicate matrix (albite and mica, occurring as needles). C. "Exsolution" of sudburyite (grey) in ferrian chromite (FeCr) with chalcopyrite (Cp). D. "Exsolution" of sudburyite (grey) in ferrian chromite. E. Several PGM (mertieite, geversite: white) in a silicate matrix (black) of ferrian chromite (FeCr). F. PGM (geversite and two-phase geversite-sperrylite grain) in a fractured crystal of chromite $(\mathrm{Cr})$; silicate matrix (black) contains trail of chalcopyrite $(\mathrm{Cp})$. 

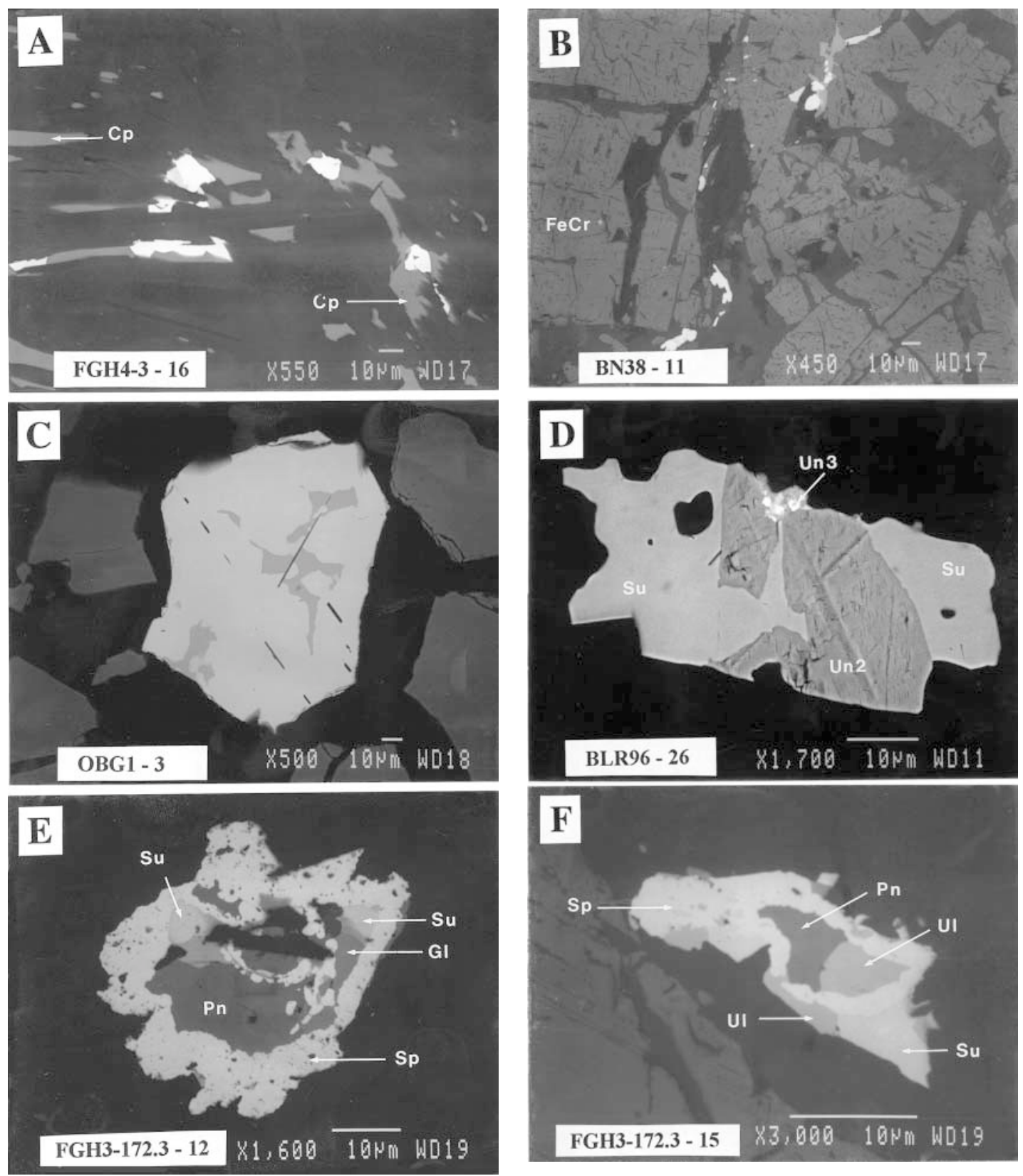

FIG. 9. Scanning electron microscope images of PGM. A. Image showing the relationships between PGM (geversite, white) and secondary chalcopyrite ( $\mathrm{Cp}$ ) in silicates (black). B. PGM (white) in fractured ferrian chromite (FeCr) with a silicate matrix (black). C. Large crystal of malanite containing inclusions of an undetermined PGM (dark grey) and an undetermined silicate (black laths). D. Complex three-phase PGM composed of Un3 (Ag-rich phase), sudburyite (Su) and Un2. E. Uncommon "concretion" with a center of pentlandite (Pn) and cobaltite-gersdorffite (Gl) and a rim of sperrylite with a weathered aspect (Sp) and sudburyite (Su). F. Uncommon "concretion" with a center of pentlandite (Pn) and ullmannite (U1) and a rim of sperrylite (Sp) and sudburyite (Su). 


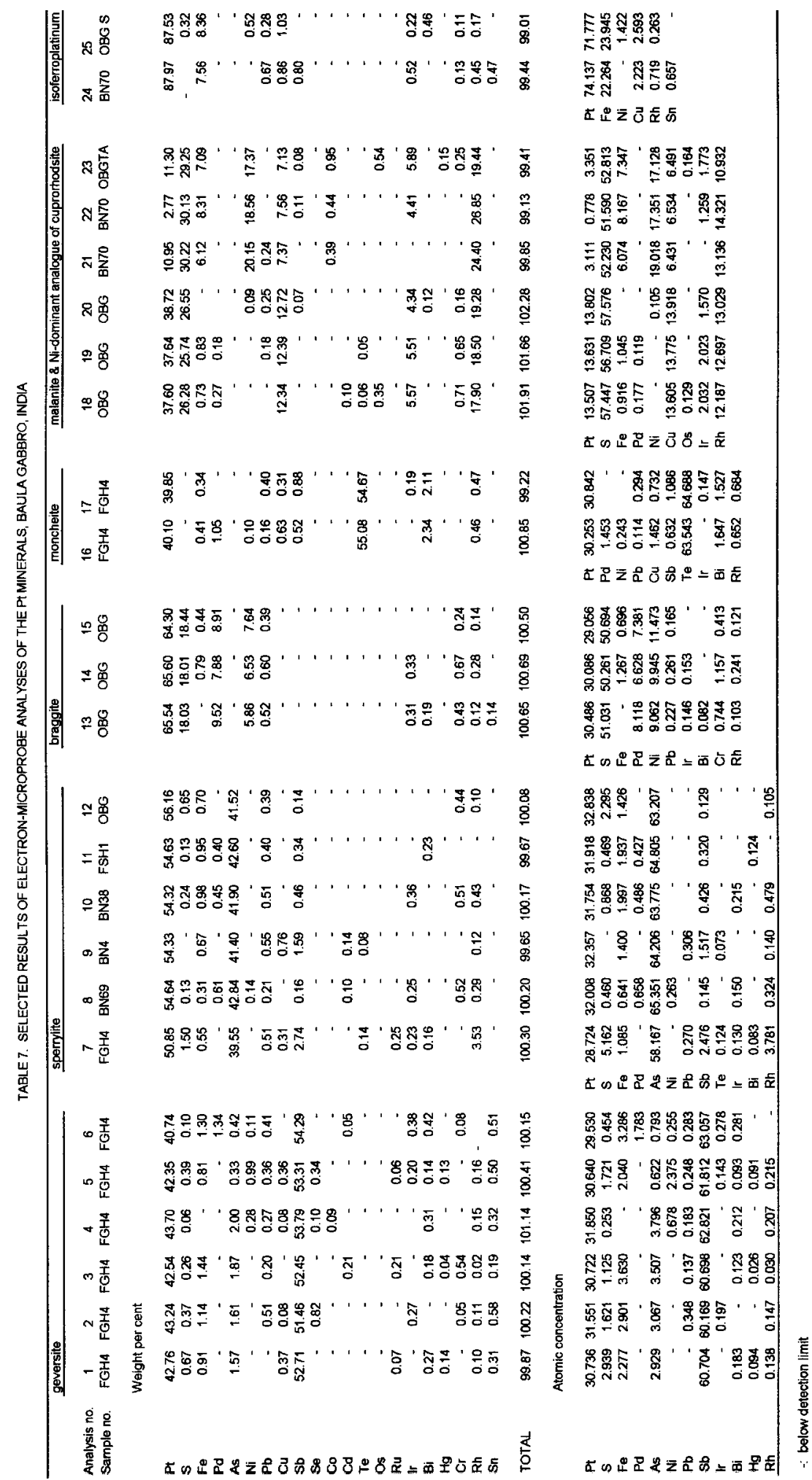




\section{Braggite}

Braggite occurs both in type-1 and type-2B BMSfree assemblages, where it forms relatively large grains (up to $70 \times 30 \mu \mathrm{m}$ ). Analyses show broad compositional variations, with $\mathrm{Pt}$ ranging from 44.18 to 80.32 wt. \%, and Pd, from 1.05 to 25.93 wt.\% and commonly increasing toward the crystal rim (Fig. 10, Table 7).

There are two populations of braggite (Fig. 10), one Pt-rich and restricted to type- 1 mineralization, with the formula $\quad\left(\mathrm{Pt}_{0.56-0.89} \mathrm{Ni}_{0.03-0.23} \mathrm{Pd}_{0.02-0.24} \mathrm{Fe}_{0-0.03}\right.$ $\left.\mathrm{Cr}_{0-0.02}\right) \mathrm{S}_{1.00-1.04}$, and the other Pd-rich and restricted to Type-2B assemblages, with the formula $\left(\mathrm{Pt}_{0.35-0.60}\right.$ $\left.\mathrm{Ni}_{0.16-0.25} \mathrm{Pd}_{0.13-0.43} \mathrm{Fe}_{0-0.09} \mathrm{Cr}_{0-0.04}\right) \mathrm{S}_{1.01-1.04}$. Although, according to IMA nomenclature, compositions in which Pd exceeds Pt correspond to vysotskite, the few compositions obtained here plot at the vysotskite-braggite limit (Fig. 10).

In most instances, the Ni contents of the two braggite populations are almost constant (around 6-7 wt.\%), and this differs from trends recorded for braggite from the Bushveld Complex (Fig. 10), where Ni increases with proportion of Pd (indicating coupled substitutions of $\mathrm{Pd}+\mathrm{Ni}$ for Pt). Verryn \& Merkle (1994) concluded that the Ni content of braggite depends on the temperature of formation, braggite with a lower $\mathrm{Ni}$ content reflecting a lower temperature in S-rich environments. On the other hand, similar compositions, rich in both PtS and $\mathrm{NiS}$, and poor in PdS, have been reported by Cabri et al. (1978) and Barkov et al. (1995).

The braggite from the Baula Complex has low Fe, $\mathrm{Pb}$ and $\mathrm{Cr}$ and $\mathrm{Rh}$ contents. The presence of $\mathrm{Pb}$ is particularly interesting because it does not appear to have been recorded previously in braggite. The $\mathrm{Cr}$ cannot be attributed to nearby chromite because the braggite grains are not associated with chromite. Thus it must, together with $\mathrm{Fe}$, be in solid solution in the braggite, as has been described for laurite by Merkle \& Gräser (1998).

\section{Sperrylite-geversite}

Sperrylite is a ubiquitous PGM in all three types of assemblages, and occurs in almost all samples, but it is most abundant in type-2B assemblages, where it coexists with geversite, commonly as two- phase grains. It is also the only free PGM found in alluvial concentrates. The sperrylite shows minor variations in composition (Table 7) that mainly reflect coupled substitutions of $\mathrm{Sb}$ $+\mathrm{S}$ for As and the incorporation of Pd $(<1.97 \mathrm{wt} . \%)$, Rh (3.53 wt.\%), Ir (0.53 wt.\%), Fe (2.00 wt.\%), Ni (0.26 wt.\%), $\mathrm{Pb}(0.74$ wt.\%) and $\mathrm{Cu}(0.76$ wt.\%). These data pertain to one-phase grains, for which the following structural formula applies: $\left(\mathrm{Pt}_{0.82-1.05} \mathrm{Rh}_{0-0.11} \mathrm{Pd}_{0-0.09}\right.$ $\left.\mathrm{Fe}_{0-0.09}\right)\left(\mathrm{As}_{1.75-2.02} \mathrm{~S}_{0-0.16} \mathrm{Sb}_{0-0.09}\right)$.

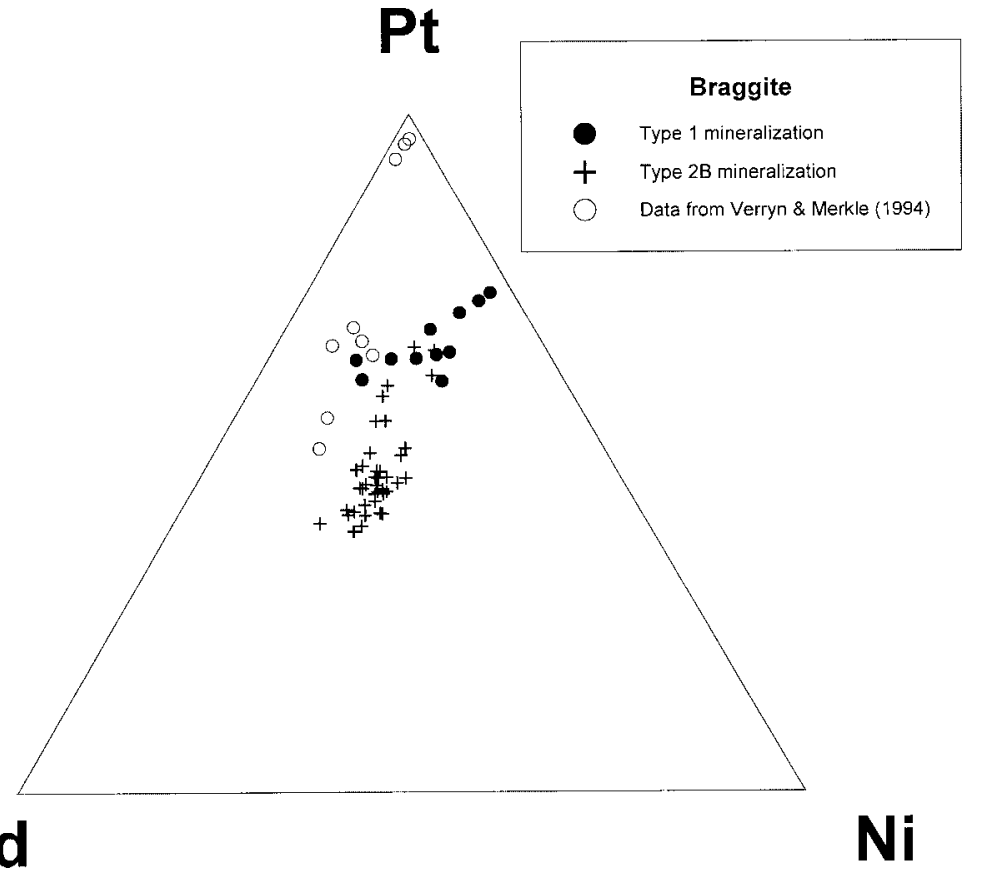

FIG. 10. Pt-Pd-Ni diagram (atomic concentration) for braggite. Filled circles: type-1 assemblage, crosses: type-2B assemblage. Open circles: data from Verryn \& Merkle (1994). 
Geversite was found both as isolated grains and as two-phase (geversite - sperrylite or geversite mertieite-II) grains. It shows substitution of S + As for $\mathrm{Sb}$ and incorporation of the same minor elements as for sperrylite (Table 7), but $\mathrm{Sn}$ is also present in significant amounts (0.19-1.04 wt.\%, average 0.39 wt.\%). The structural formula corresponds to $\left(\mathrm{Pt}_{0.89-0.99} \mathrm{Fe}_{0.01-0.10}\right.$ $\left.\mathrm{Pd}_{0-0.05} \mathrm{Ni}_{0-0.07} \mathrm{Sn}_{0-0.05}\right)\left(\mathrm{Sb}_{1.69-1.95} \mathrm{As}_{0.02-0.10} \mathrm{~S}_{0-0.09}\right)$.

In terms of the phase diagram for the system Pt-As$\mathrm{Sb}$ (Fig. 11), there seems to be a broad miscibility-gap between sperrylite and geversite. The PtAs 2 content of geversite reaches a maximum of $7.6 \mathrm{~mol} . \%$, whereas the $\mathrm{PtSb}_{2}$ component does not exceed $4.5 \mathrm{~mol} \%$ in sperrylite. Furuseth et al. (1967) reported a miscibility gap between 10 and $65 \mathrm{~mol} \% \mathrm{PtSb}_{2}$ in the system $\mathrm{PtAs}_{2}-$ $\mathrm{PtSb}_{2}$ at $1000^{\circ} \mathrm{C}$, but Johan et al. (1989) reported a sperrylite-geversite solid solution within this gap (Fig. 11). Cabri \& Laflamme (1976) also mentioned Sb replacing As to a very small extent in sperrylite from Sudbury, although only to a maximum of $0.98 \mathrm{wt} . \% \mathrm{Sb}$ for sperrylite not coexisting with geversite.

Feather (1976) described an association of sperrylite and geversite from the Witwatersrand reefs, where geversite occurs either as inclusions in PGE alloys or "intermixed" with sperrylite, both forming a late coat- ing on weathered PGM. Tarkian \& Stumpfl (1975) described geversite from the Bushveld Complex (in mineralization associated with a dunite pipe at the Driekop mine) as being both isolated and intergrown with sperrylite (i.e., a similar paragenesis to the association observed in the Baula Complex), but they did not report compositions.

\section{Malanite and Ni-dominant analogue of cuprorhodsite}

Thiospinel was identified only in type- 1 assemblages, where it forms relatively large crystals up to 140 $\times 90 \mu \mathrm{m}$. Electron-microprobe analyses reveal two main compositions (Fig. 12, Table 7). The first composition plots at the limit between malanite and cuprorhodsite, and is $\mathrm{Cu}$-rich (9.94 to $12.91 \mathrm{wt} . \%$ ) and Ni-poor (0 to $0.33 \mathrm{wt} . \%$ ). The compositional range can be expressed as $\left(\mathrm{Rh}_{0.53-1.23} \mathrm{Pt}_{0.64-0.99} \mathrm{Ir}_{0-0.39}\right)\left(\mathrm{Cu}_{0.79-}\right.$ $\left.{ }_{0.98} \mathrm{Fe}_{0-0.25} \mathrm{Ni}_{0-0.03}\right) \mathrm{S}_{3.96-4.07}$. The second composition plots in the cuprorhodsite field, but is Ni-rich (13.40 to 21.09 wt.\%), Cu-poor (6.71 to 8.22 wt.\%), and relatively rich in $\mathrm{Rh}$. The compositional range can be expressed as $\left(\mathrm{Rh}_{0.70-1.12} \mathrm{Pt}_{0.05-0.23} \mathrm{Ir}_{0-0.31}\right)\left(\mathrm{Ni}_{0.91-1.38} \mathrm{Cu}_{0.43-0.53}\right.$ $\left.\mathrm{Fe}_{0.30-0.64}\right) \mathrm{S}_{3.90-3.93}$.

\section{Pt}

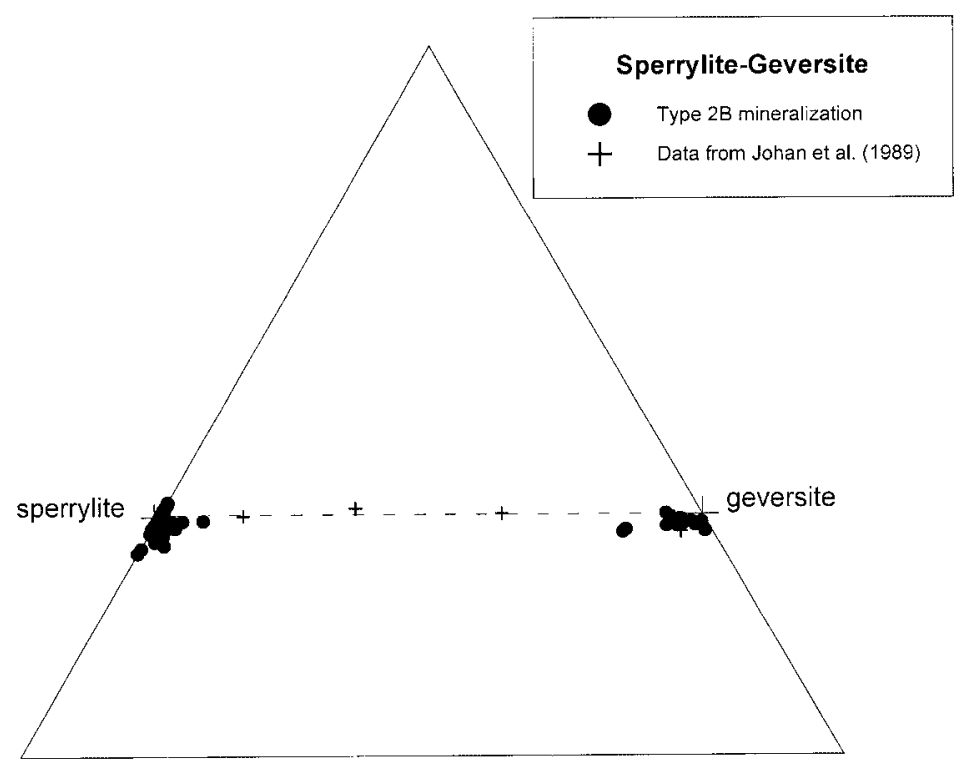

\section{As}

FIG. 11. Pt-As-Sb diagram (atomic concentration) for sperrylite and geversite. Crosses: data from Johan et al. (1989); filled circles: this study. 


\section{Moncheite}

Two grains of moncheite were found in a single sample enriched in ferrian chromite from a type-2B assemblage, and both grains occur within tremolitic amphibole. Their composition is close to the ideal formula $(\mathrm{Pt}, \mathrm{Pd})(\mathrm{Te}, \mathrm{Bi})_{2}$ with, however, a very low amount of $\mathrm{Pd}$ and $\mathrm{Bi}$ (Table 7). The average composition, obtained from four analyses on the two grains, is $\left(\mathrm{Pt}_{0.92} \mathrm{Cu}_{0.04}\right.$ $\left.\mathrm{Pd}_{0.03} \mathrm{Ni}_{0.01}\right)\left(\mathrm{Te}_{1.91} \mathrm{Bi}_{0.05} \mathrm{Sb}_{0.03}\right)$.

\section{Laurite}

Laurite (Table 8) was identified in all three types of mineralization. In type-1 assemblages, it occurs within silicates or chromite nodules; in type-2A assemblages, it is found as composite grains associated with BMS (chalcopyrite and cobaltite-gersdorffite), sperrylite or hollingworthite. In type-2B assemblages, it occurs as relatively large crystals (up to $100 \times 100 \mu \mathrm{m}$ ) associated with silicates.
Figure 13 shows that laurite in type- 1 assemblages has a wide compositional range, with almost no As $(<0.2$ wt.\%), as opposed to types-2A and -2B assemblages, in which the laurite is systematically enriched in As (1.01\% to $5.97 \mathrm{wt} . \%$, with As substituting for S). The latter also contain, on average, more Pt and less Ir than laurite in type- 1 assemblages.

The presence of $\mathrm{Cr}$ in laurite in both assemblages (maximum of $0.81 \mathrm{wt} . \%$ ) cannot be an artifact, as the laurite forms large crystals. This finding confirms the observations of Merkle \& Gräser (1998) regarding the presence of $\mathrm{Cr}$ in solid solution in laurite (the same observation is made for malanite).

The compositional range is $\left(\mathrm{Ru}_{0.44-0.91} \mathrm{Os}_{0.01-0.49}\right.$ $\left.\mathrm{Ir}_{0-0.08} \mathrm{Rh}_{0.02-0.12}\right)\left(\mathrm{S}_{1.88-2.01} \mathrm{As}_{0-0.15}\right)$. Detailed point analyses showed that the large crystals of laurite in type1 assemblages are not zoned, unlike laurite from the Bird River Sill, Manitoba (Ohnenstetter et al. 1986). An Os-rich core was, however, observed in a large crystal of laurite from sample BN40.

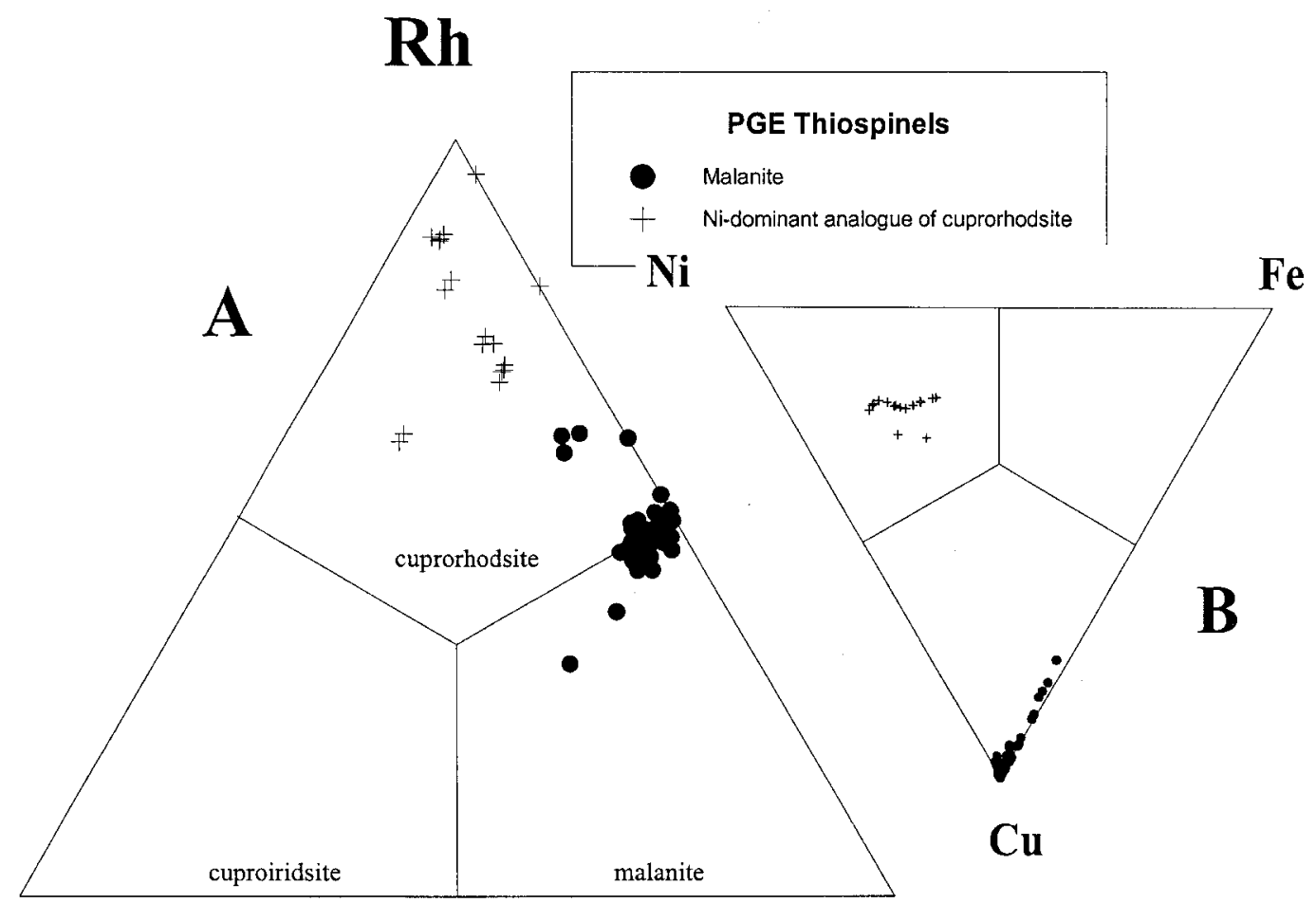

Ir

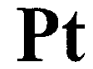

FIG. 12. Composition of the PGE thiospinels (atomic concentration) A) in terms of the diagram Rh-Ir-Pt, and B) in terms of the diagram $\mathrm{Cu}-\mathrm{Fe}-\mathrm{Ni}$. Closed circles: malanite, crosses: "Ni-dominant analogue of cuprorhodsite". 
TABLE 8. SELECTED RESULTS OF ELECTRON-MICROPROBE ANALYSES OF THE Ru, Rh AND Os MINERALS, BAULA COMPLEX, INDIA

\begin{tabular}{|c|c|c|c|c|c|c|c|c|c|c|}
\hline \multicolumn{7}{|c|}{ laurite } & \multicolumn{2}{|c|}{ hollingworthite } & \multicolumn{2}{|c|}{ osmium * } \\
\hline $\begin{array}{l}\text { Anaiysis no } \\
\text { Sample no. }\end{array}$ & $\begin{array}{c}1 \\
\text { BN37 }\end{array}$ & $\begin{array}{c}2 \\
8 N 4\end{array}$ & $\begin{array}{c}3 \\
F S H 1\end{array}$ & $\begin{array}{c}4 \\
O B G\end{array}$ & $\begin{array}{c}5 \\
\mathrm{FSH} 1\end{array}$ & $\begin{array}{c}6 \\
\text { FSH1 }\end{array}$ & $\begin{array}{c}7 \\
\text { FGH4 }\end{array}$ & $\begin{array}{c}8 \\
\text { BN4 }\end{array}$ & $\begin{array}{c}9 \\
\text { BLR25 }\end{array}$ & $\begin{array}{c}10 \\
F 2-1\end{array}$ \\
\hline
\end{tabular}

\begin{tabular}{|c|c|c|c|c|c|c|c|c|c|c|}
\hline & leight & cent & & & & & & & & \\
\hline $\begin{array}{l}\mathrm{Pl} \\
\mathrm{S} \\
\mathrm{Fe}\end{array}$ & $\begin{array}{r}0.57 \\
35.50 \\
1.76\end{array}$ & $\begin{array}{r}31.85 \\
3.80\end{array}$ & $\begin{array}{r}2.44 \\
35.71 \\
1.77\end{array}$ & $\begin{array}{r}0.16 \\
35.35 \\
0.22\end{array}$ & $\begin{array}{r}3.87 \\
34.14 \\
1.10\end{array}$ & $\begin{array}{r}2.44 \\
35.71 \\
1.77\end{array}$ & $\begin{array}{r}5.21 \\
15.24 \\
1.29\end{array}$ & $\begin{array}{r}14.87 \\
13.93 \\
1.33\end{array}$ & $\begin{array}{r}4.68 \\
1.91\end{array}$ & $\begin{array}{r}2.03 \\
4.66\end{array}$ \\
\hline Pd & - & - & - & 0.20 & - & - & 0.52 & 1.61 & 1.51 & 4.66 \\
\hline As & 0.74 & 5.97 & 3.22 & - & 4.85 & 3.22 & 31.36 & 35.20 & 0.70 & - \\
\hline $\mathrm{Ni}$ & 0.19 & 1.13 & 0.09 & 0.06 & 0.08 & 0.09 & 0.38 & 2.45 & - & - \\
\hline $\mathrm{Pb}$ & - & - & - & - & - & - & 0.21 & - & - & \\
\hline $\mathrm{Cu}$ & - & - & 0.31 & - & 0.39 & 0.31 & 0.15 & - & 0.63 & 0.27 \\
\hline $\mathrm{Sb}$ & 0.08 & - & - & - & - & - & - & 0.17 & 0.23 & \\
\hline Co & 0.32 & 3.04 & - & - & 0.18 & - & - & 0.89 & - & - \\
\hline $\mathrm{Au}$ & 0.32 & - & - & - & - & - & - & - & - & 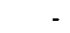 \\
\hline Te & - & - & 0.09 & - & - & 0.09 & - & - & - & - \\
\hline Os & 6.83 & 20.61 & 0.97 & 16.76 & 2.28 & 0.97 & - & - & 36.71 & 34.38 \\
\hline Ru & 49.08 & 29.38 & 52.47 & 44.62 & 49.57 & 52.47 & 0.38 & 10.59 & 10.62 & 13.12 \\
\hline Ir & 2.76 & 0.29 & - & 2.42 & - & - & 2.77 & - & 30.50 & 29.76 \\
\hline$B i$ & 0.19 & - & - & - & 0.13 & - & - & - & - & - \\
\hline $\mathrm{Hg}$ & - & - & 0.10 & - & - & 0.10 & - & - & - & \\
\hline $\mathrm{Cr}$ & 0.81 & 0.20 & - & 0.07 & - & - & 0.49 & 0.22 & 7.94 & 9.67 \\
\hline Rh & 1.11 & 2.15 & 3.24 & 1.11 & 3.95 & 3.24 & 41.92 & 19.05 & 0.55 & 0.58 \\
\hline TOTAL & 100.26 & 98.43 & 100.42 & 100.97 & 100.53 & 100.42 & 99.92 & 100.31 & 94.47 & 94.46 \\
\hline
\end{tabular}

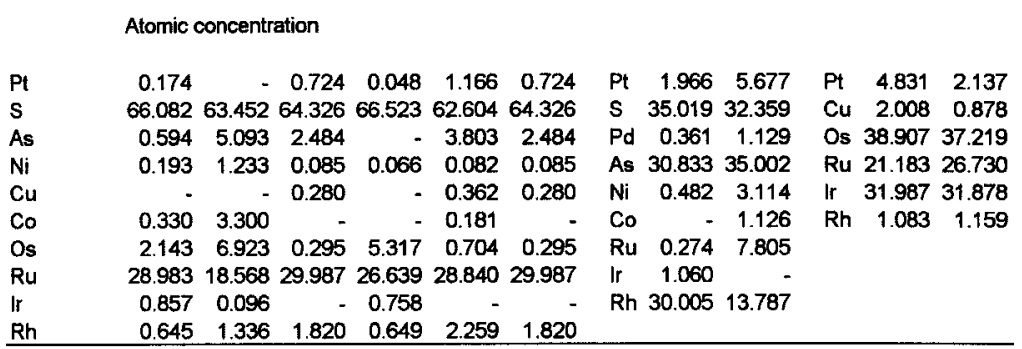

$-:$ below detection limit

* low analytical total due to the small size of the grains. Atomic concentration calculated without $\mathrm{Cr}$.

\section{Hollingworthite}

Hollingworthite occurs in all three types of mineralization. It forms discrete crystals in type-1 assemblages, and both discrete and complex associations in assemblages of Types $2 \mathrm{~A}$ and $2 \mathrm{~B}$. The discrete crystals contain a variable amount of $\mathrm{Pt}(0$ to 6.13 wt.\%), Ir (0 to 22.69 wt.\%) and $\mathrm{Ru}(0$ to $13.10 \mathrm{wt} . \%)$, corresponding to the general formulae (Rh,Pt,Ir, Ru)AsS. Minor amounts of $\mathrm{Pd}, \mathrm{Ni}, \mathrm{Sb}$ and $\mathrm{Ir}$ are recorded in composite grains in types-2A and -2B assemblages (Table 8).

\section{Osmium}

Osmium was not found in the breccia-type PGE mineralization, but it does occur as inclusions in chromite crystals from the chromitite layers of the peridotite unit. This is a common mode of occurrence for osmium (commonly with laurite) in chromitites, especially from ophiolites (Augé \& Legendre 1994, Augé \& Maurizot 1995). Osmium was also identified in a chromite crystal from an alluvial concentrate. The chromite in this case was probably derived from a chromitite layer in the peridotites. The compositions, with Os slightly dominant over Ir and Ru (Fig. 13, Table 8) are strongly affected by excitation of the host chromite, and this also explains the low analytical totals in Table 8.

\section{$S b-T e-B i-P t-P d$ compounds}

Three minerals belonging to this system were clearly identified (sudburyite PdSb, mertieite-II $\mathrm{Pd}_{8} \mathrm{Sb}_{3}$ and merenskyite $\mathrm{PdTe}_{2}$ ). In addition, several phases are either new species or uncommon solid-solutions. Compositions of $\mathrm{Sb}-\mathrm{Te}-\mathrm{Bi}$ minerals were plotted on both 


\section{Ru}

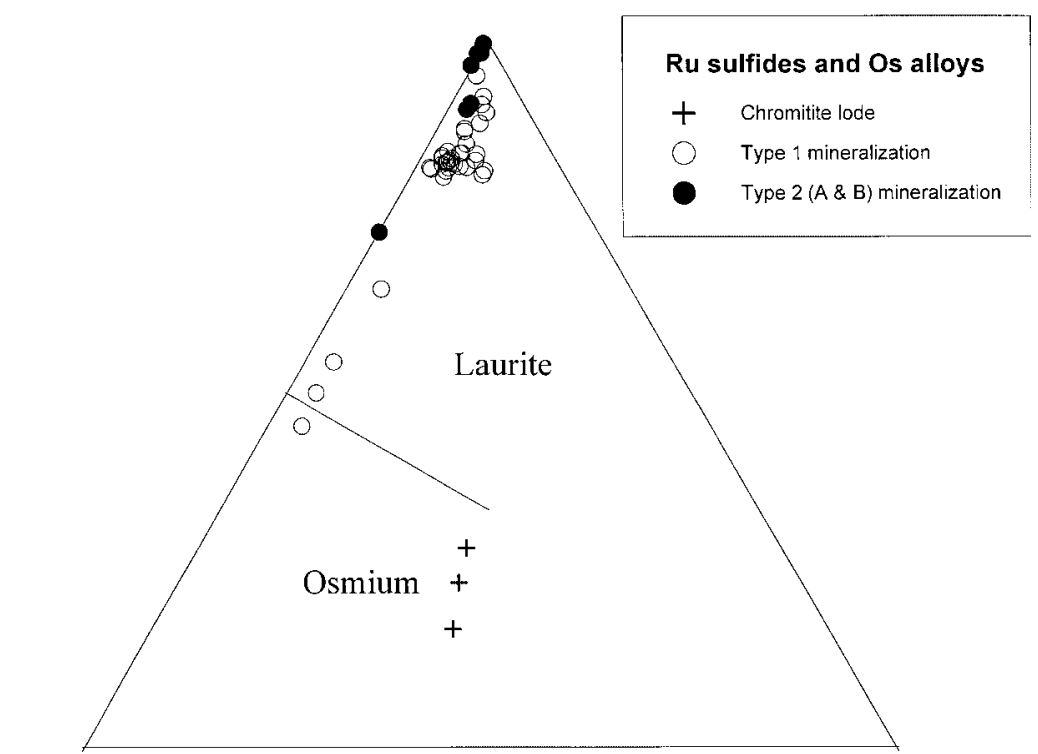

\section{Os}

FIG. 13. Composition of Ru-Os-Ir sulfide (laurite) and alloy (osmium) found in chromite lodes and in type- 1 and -2 assemblages (atomic concentration).

triangular (Fig. 14) and binary (Fig. 15) diagrams. Apart from merenskyite containing 5-10 wt.\% Pt, they are all $\mathrm{Pd}$ minerals and close to the system Te-Sb, with limited incorporation of $\mathrm{Bi}$. Figure 15 shows that except for one composition (Un7), the "unidentified" Sb-TeBi compounds are all characterized by a metal:semimetal ratio between $1: 1$ and 1:2. It is unlikely, therefore, that they belong to the $\mathrm{PdSb}$ (sudburyite) - PdBi (sobolevskite) - PdTe (kotulskite) system, in which solid solutions are poorly defined. Hoffman \& MacLean (1976) experimentally demonstrated substantial substitution of $\mathrm{Pd}$ for both $\mathrm{Bi}$ and $\mathrm{Te}$ in merenskyite at high temperature, and also the existence of a complete solidsolution between merenskyite and kotulskite from $575^{\circ}$ to $710^{\circ} \mathrm{C}$. An extension of this solid solution to the more complex $\mathrm{Pd}(\mathrm{Sb}, \mathrm{Te}, \mathrm{Bi})_{2}$ and $\mathrm{Pd}(\mathrm{Sb}, \mathrm{Te}, \mathrm{Bi})$ systems could explain some of the compositions obtained here.

\section{Sudburyite and related compositions}

Sudburyite, with a formula corresponding to the range $\left(\mathrm{Pd}_{0.91-1.02} \mathrm{Ni}_{0-0.08} \mathrm{Cu}_{0-0.03}\right)\left(\mathrm{Sb}_{0.84-0.98} \mathrm{Te}_{0-0.10}\right.$

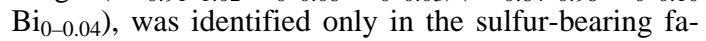
cies (type 2A), where it occurs either isolated in silicates, associated with BMS, or in ferrian chromite. Its composition is close to ideal PdSb (Table 9), with traces of Pt (1.76 wt.\%), Ni (1.94 wt.\%), Cu (0.64 wt.\%), As (1.50 wt.\%), Sn (0.34 wt.\%) and $\mathrm{Hg}(0.72$ wt.\%), these being the maximum values recorded for single-phase grains. $\mathrm{Cr}$ and $\mathrm{Fe}$ attributed to excitation of the host ferrian chromite. Te $(<5.31 \mathrm{wt} . \%)$ and, to a lesser extent, $\mathrm{Bi}(<3.46$ wt.\%) substitute for Sb (Figs. 14, 15). In the first paper to describe sudburyite, Cabri \& Laflamme (1974) mentioned the presence of nickeloan varieties $(<9.2 \mathrm{wt} . \% \mathrm{Ni})$ and the incorporation of $\mathrm{Bi}(<5.4 \mathrm{wt} . \%)$, Te (3.9 wt.\%) and As (2.04 wt.\%).

A second composition (Un7) belonging to the system $\mathrm{Pd}-\mathrm{Sb}-\mathrm{Bi}$, and with a metal:semimetal ratio close to 1 , was found in one sample of a type-2A assemblage; it occurs in fractures in ferrian chromite filled with secondary silicates. This mineral was recorded only in a single sample, but is characterized by significant substitution of $\mathrm{Sb}$ for $\mathrm{Bi}$ with a $\mathrm{Pd}$ atomic concentration around 0.50 (Figs. 14, 15, Table 10). This substitution trend is not seen in sudburyite, in which Sb tends to be replaced by $\mathrm{Te}$ and not by $\mathrm{Bi}$. The formula is $\left(\mathrm{Pd}_{0.97-1.02}\right.$ $\left.\mathrm{Pt}_{0-0.01}\right)\left(\mathrm{Sb}_{0.33-0.88} \mathrm{Bi}_{0.11-0.49} \mathrm{Te}_{0-0.20}\right)$, with the more $\mathrm{Bi}-$ rich composition corresponding to $\mathrm{Pd}\left(\mathrm{Sb}_{0.50} \mathrm{Bi}_{0.50}\right)$. This is far from the ideal composition of sobolevskite, $\mathrm{PdBi}$, but there seems to be no data on $\mathrm{PdSb}-\mathrm{PdBi}$ solid solution. 


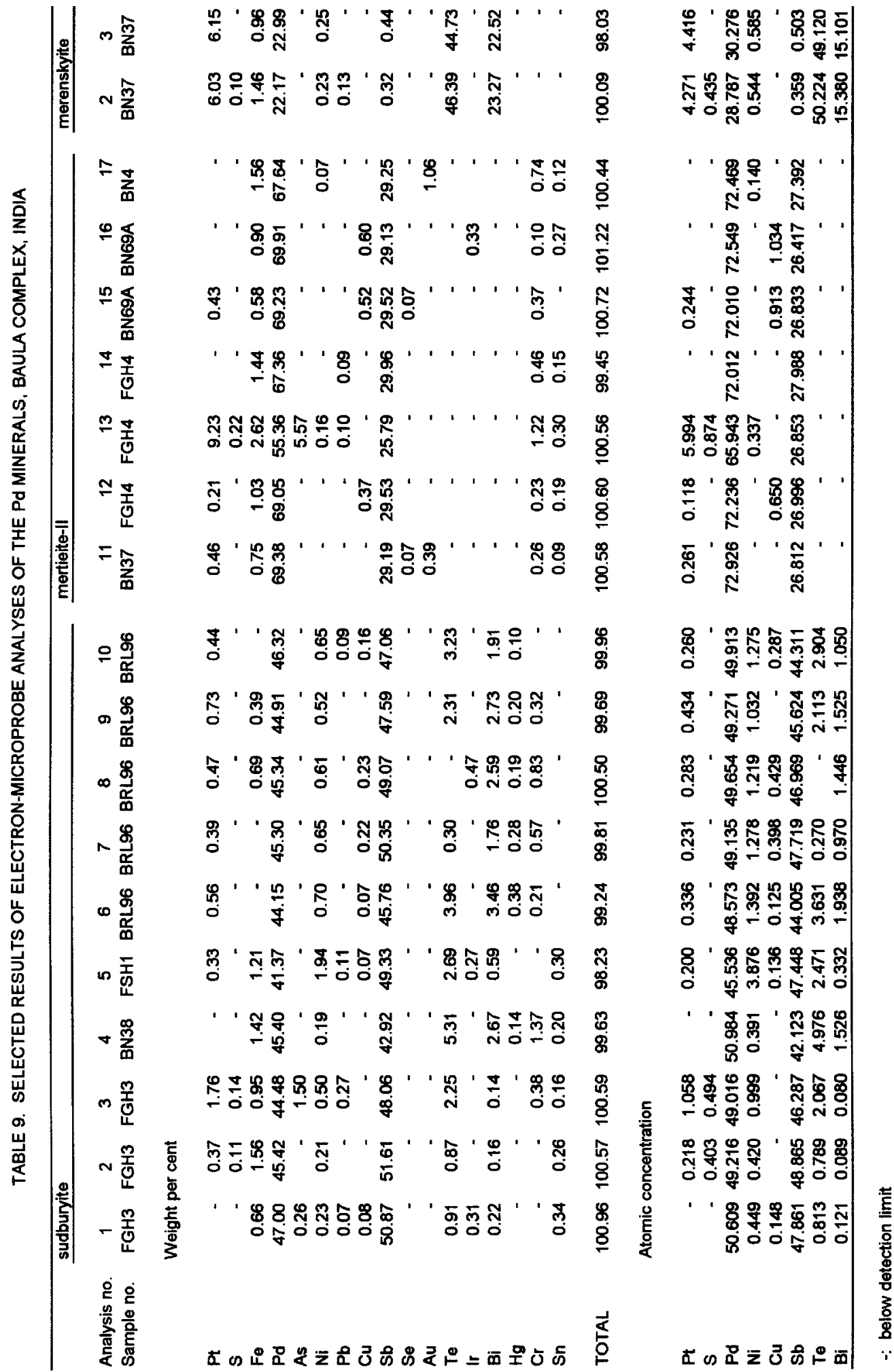




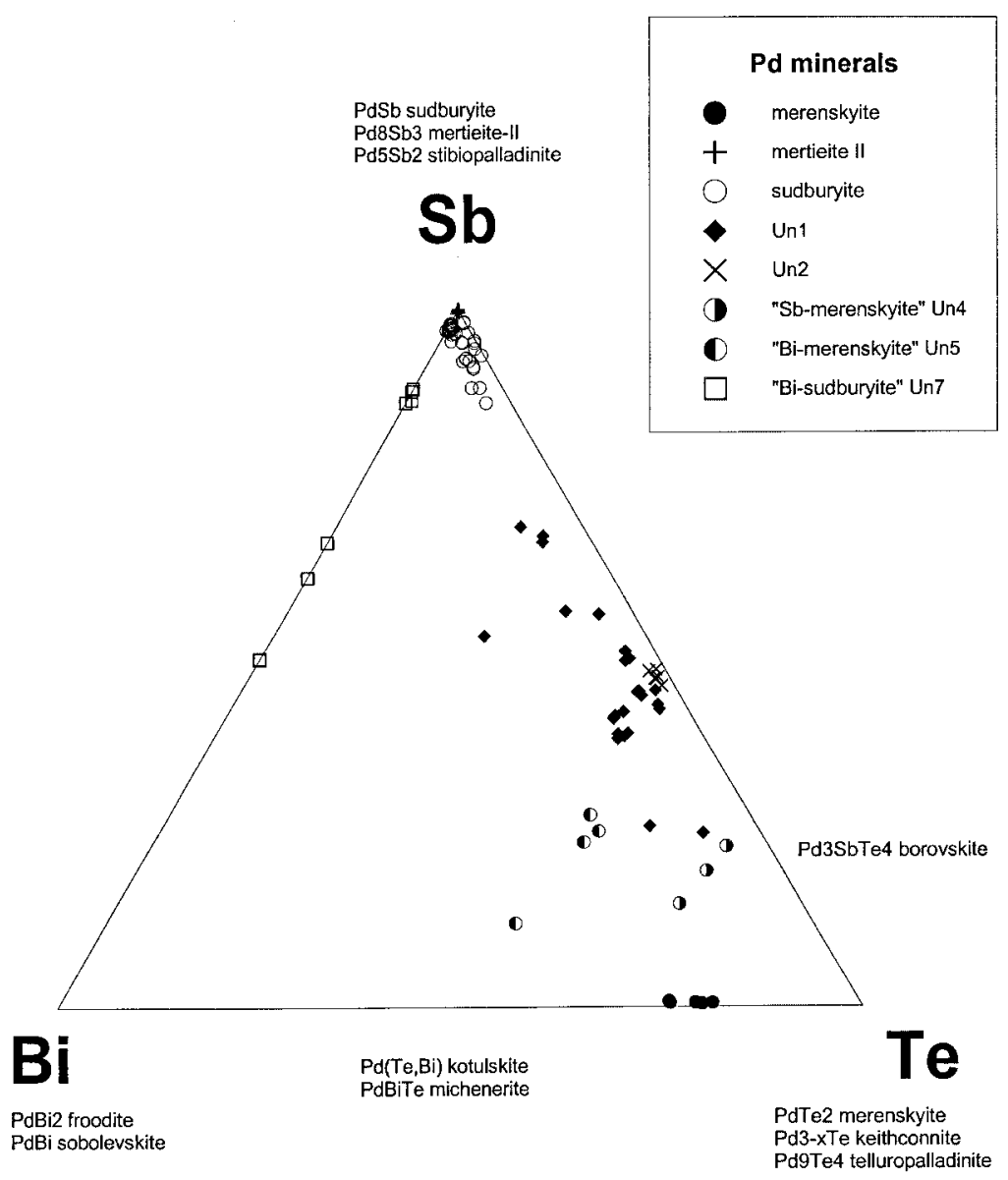

FIG. 14. Sb-Bi-Te diagram (atomic concentration) for the Pd minerals.

\section{Mertieite-II}

Another Sb-Pd compound, mertieite-II $\left(\mathrm{Pd}_{8} \mathrm{Sb}_{3}\right)$, was identified on the basis of its composition (Table 9), which gives a better agreement with the stoichiometry of mertieite-II than of stibiopalladinite $\left(\mathrm{Pd}_{5} \mathrm{Sb}_{2}\right)$ although, strictly speaking, mertieite-II and stibiopalladinite can only been distinguished by X-ray diffraction. The mineral is fairly common and was identified in four samples from assemblages of types $2 \mathrm{~A}$ and $2 \mathrm{~B}$ (more common) where it occurs a) as isolated grains in silicate, b) as two-phase grains with sperrylite in silicates (common), c) within ferrian chromite, and (d) in fractures in ferrian chromite. Unlike sudburyite, mertieite-II does not contain $\mathrm{Bi}$ or Te, and its composition is close to the ideal $\mathrm{Pd}_{8} \mathrm{Sb}_{3}$. The formula obtained for non-composite grains is $\left(\mathrm{Pd}_{7.87} \mathrm{Pt}_{0.08} \mathrm{Cu}_{0.04}\right)_{\Sigma 7.99}$ $\left(\mathrm{Sb}_{2.98}\right)_{\Sigma 2.98}$ (Fig. 14). Minor Pt (0-0.94 wt.\%), Cu (00.60 wt. \%) and $\mathrm{Au}(0-1.06$ wt.\%) were recorded.

\section{Merenskyite and related compositions}

Merenskyite was found in only one sample (type2A assemblage), where it occurs in silicates adjacent to trails of BMS. Its composition (Table 9, Figs. 14, 15) differs from the ideal $\mathrm{PdTe}_{2}$ by containing large amounts of $\mathrm{Pt}(<9.0$ wt.\%) and $\mathrm{Bi}(<23.27$ wt.\%), plus minor proportions of $\mathrm{Fe}, \mathrm{Ni}$, and $\mathrm{Sb}$; the formula is close to $\left(\mathrm{Pd}_{0.88} \mathrm{Pt}_{0.13}\right)_{\Sigma 1.01}\left(\mathrm{Te}_{1.53} \mathrm{Bi}_{0.47}\right)_{\Sigma 2.00}$.

A second phase (Un4) was identified in the same sample, occurring in silicates and also included in chalcopyrite. The phase could correspond to an Sb-rich merenskyite with up to 14.39 wt.\% Sb [Cabri \& Laflamme (1976) give a maximum of $0.7 \mathrm{wt} . \% \mathrm{Sb}$ for merenskyite], but its metal:semimetal ratio is close to 0.385:0.615 (Fig. 15, Table 10), and its formula is best calculated on the basis of five atoms: $\left(\mathrm{Pd}_{1.78} \mathrm{Ni}_{0.10}\right.$ $\left.\mathrm{Cu}_{0.03}\right)_{\Sigma 1.91}\left(\mathrm{Te}_{2.19} \mathrm{Sb}_{0.58} \mathrm{Bi}_{0.30}\right)_{\Sigma 3.07}$. Compared to the coexisting merenskyite, the phase contains no Pt, has higher Pd and $\mathrm{Sb}$, less $\mathrm{Bi}$, and a similar amount of Te. 


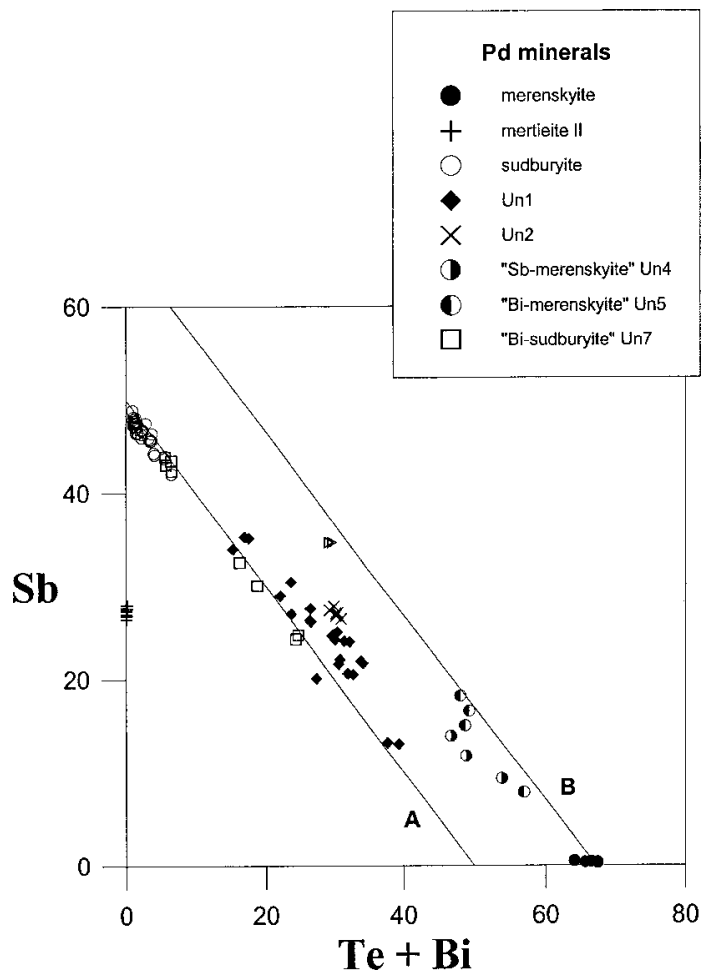

FIG. 15. $(\mathrm{Te}+\mathrm{Bi})-\mathrm{Sb}$ correlation diagram (atomic concentration) for the Pd minerals. Line A corresponds to the $1: 1$ metal:semimetal ratio; whereas line $\mathrm{B}$ corresponds to a $1: 2$ ratio.

A third phase (Un5), comparable to merenskyite, was found in two samples containing type-2A assemblages, within silicates adjacent to BMS and within BMS in ferrian chromite crystals. On the basis of three atoms, its formula corresponds to $\left(\mathrm{Pd}_{0.96} \mathrm{Ni}_{0.03} \mathrm{Cu}_{0.02}\right.$ $\left.\mathrm{Pt}_{0.02}\right)_{\Sigma 1.03}\left(\mathrm{Te}_{1.04} \mathrm{Bi}_{0.48} \mathrm{Sb}_{0.43} \mathrm{~S}_{0.01}\right)_{\Sigma 1.96}$. The phase is probably $\mathrm{Sb}-\mathrm{Bi}$-enriched merenskyite (Figs. 14, 15, Table 10). Again, no similar composition appears to have been described in the literature.

Cabri \& Laflamme (1976) described three varieties of merenskyite at Sudbury: bismuthian merenskyite (14.8 wt.\% Bi), nickeloan bismuthian merenskyite (14.2 wt. $\% \mathrm{Bi}$ and $6.1 \mathrm{wt} . \% \mathrm{Ni}$ ) and platinian bismuthian merenskyite (18.8 wt.\% Pt and 36.4 wt.\% Bi). Only the last composition was examined by $\mathrm{X}$-ray diffraction and gave parameters comparable to those of synthetic $\mathrm{PdTe}_{2}$. Those authors also suggested a partial solid-solution between merenskyite and michenerite PdTeBi.

Gervilla et al. (1997) described extensive substitution of Bi for Te and of Ni for Pd in merenskyite of the Las Aguilas deposit (where it is the most abundant telluride), but in most cases $\mathrm{Pt}$ was not detected and $\mathrm{Sb}$ was not mentioned, in contrast to the merenskyite in the Baula Complex.

\section{Phase Un1}

Phase Un1 (Table 10) was identified in seven samples containing a type-2A assemblage, in which the PGM occur adjacent to BMS, in silicates associated with BMS trails (or not), within ferrian chromite, and as inclusions in BMS. Mineral phase $\mathrm{Un} 1$ is a $\mathrm{Pd}, \mathrm{Te}, \mathrm{Sb}, \mathrm{Bi}$ compound with a metal:semimetal ratio of $0.465: 0.535$ (i.e., significantly different from the $1: 1$ ratio for sudburyite) and a complex substitution of $\mathrm{Sb}$ for $\mathrm{Te}$ in which $\mathrm{Bi}$ is also involved (Fig. 15). The following ranges of elements were recorded; $\mathrm{Pt}(0-0.77 \mathrm{wt} . \%), \mathrm{Fe}$ (0-2.79 wt.\%), Ni (0-2.58 wt.\%) and $\mathrm{Cu}(0-2.17$ wt.\%). There is a large compositional gap between sudburyite and Un1, and the simplified structural formula can be written $\mathrm{Pd}_{5}(\mathrm{Sb}, \mathrm{Te}, \mathrm{Bi})_{6}$, which is broadly similar to the $\mathrm{Pd}_{5}(\mathrm{Bi}, \mathrm{Sb})_{2} \mathrm{Te}_{4}$ given by McCallum et al. (1976).

Cabri \& Laflamme (1976) described an unnamed $\mathrm{Pd}(\mathrm{Te}, \mathrm{Sb}, \mathrm{Bi})$ mineral that they interpreted as a possible phase in the PdSb (sudburyite) - PdBi (sobolevskite) PdTe (kotulskite) system. Evstigneeva et al. (1976) suggested the existence of intermediate phases between sudburyite, sobolevskite and kotulskite, and a continuous solid-solution between PdBi and PdTe. Figure 15, however, shows a clear deficit of metals versus semimetals; the average composition obtained for material from the Baula Complex gives $\mathrm{Pd}(\mathrm{Sb}, \mathrm{Te}, \mathrm{Bi})_{1.15}$, which is too far removed from the above-mentioned system. If the existence of a solid-solution series between the $\mathrm{Pd}(\mathrm{Sb}, \mathrm{Te}, \mathrm{Bi})_{2}$ and $\mathrm{Pd}(\mathrm{Sb}, \mathrm{Te}, \mathrm{Bi})$ systems is eventually demonstrated, then the Un1 composition could belong to this series.

\section{Phase Un2}

The composition of Un2 occurs only within BMS inclusions in type-2A ferrian chromite. It is a Ni-Pd antimonotelluride, characterized by a metal:semimetal ratio of 0.43:0.57 (Fig. 15), and differs from any known species. The simplified structural formula of Un2 can be written $(\mathrm{Pd}, \mathrm{Ni})_{3}(\mathrm{Sb}, \mathrm{Te})_{4}$, which corresponds to between 18.0 and $20.6 \mathrm{wt} . \% \mathrm{Pd}$ and between 11.3 and $13.4 \mathrm{wt} . \%$ $\mathrm{Ni}$ (Table 10). Beaudoin et al. (1990) described a mineral with the formula $(\mathrm{Pd}, \mathrm{Ni})(\mathrm{Sb}, \mathrm{Te}, \mathrm{Bi})$, but this phase contains much less Ni than Un2 and much more Bi.

\section{$S b-T e-B i-A g-P d$ compounds}

An Ag-rich composition (Un3) from a three-phase grain (Fig. 9D) was detected in one sample from a type$2 \mathrm{~A}$ assemblage. The mineral forms small $(<3 \mu \mathrm{m})$ inclusions within the sudburyite-Un2 assemblage. The analysis with the highest $\mathrm{Ag}$ values (16.17 wt.\% Ag) also showed 23.87 wt.\% Pd, 21.03\% Sb, $24.52 \%$ Te and $12.81 \% \mathrm{Bi}$ (Table 10). Un3 seems to have a metal:semi- 


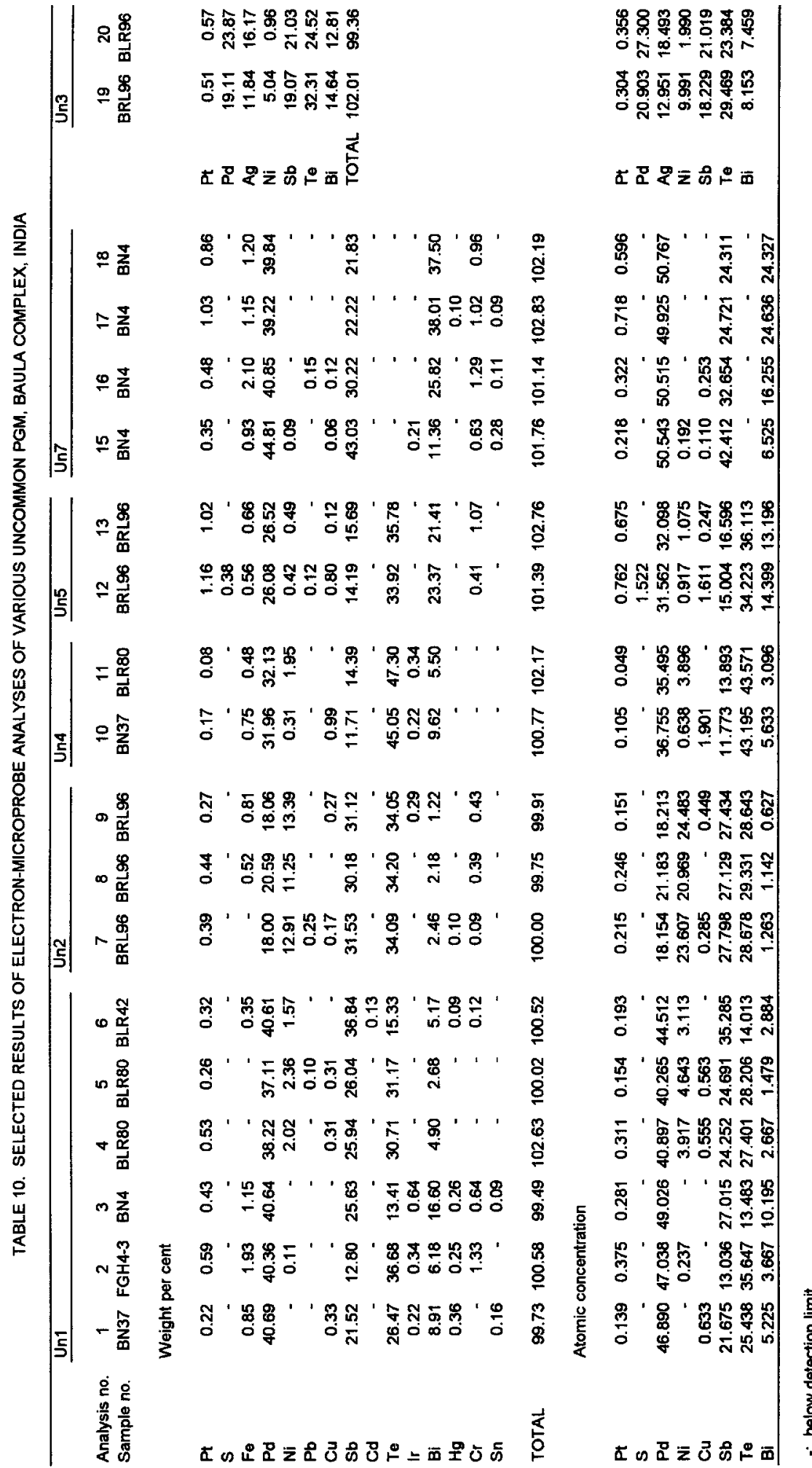


TABLE 11. SELECTED RESULTS OF ELECTRON-MICROPROBE ANALYSES OF COLORADOITE AND GOLD-SILVER ALLOY, BAULA COMPLEX, INDIA

\begin{tabular}{|c|c|c|c|c|c|c|c|c|c|c|}
\hline \multirow[b]{2}{*}{$\begin{array}{l}\text { Analysis no. } \\
\text { Sample no. }\end{array}$} & \multirow{2}{*}{$\begin{array}{c}\text { coloradoit } \\
5 \\
\text { BLR96 }\end{array}$} & & \multicolumn{2}{|c|}{ argentian gold } & \multirow[b]{2}{*}{$\begin{array}{c}3 \\
\text { BLR96 }\end{array}$} & \multirow[b]{2}{*}{$\stackrel{4}{\text { BLR96 }}$} & \multirow[b]{2}{*}{$\begin{array}{c}91 \\
\text { BN } 83\end{array}$} & \multirow[b]{2}{*}{$\begin{array}{c}92 \\
\text { BN } 83\end{array}$} & \multirow[b]{2}{*}{$\begin{array}{c}93 \\
\text { BN } 83\end{array}$} & \multirow[b]{2}{*}{$\begin{array}{c}94 \\
\text { BN } 83\end{array}$} \\
\hline & & & $\begin{array}{c}1 \\
\text { BLR96 }\end{array}$ & $\stackrel{2}{\text { BLR96 }}$ & & & & & & \\
\hline & \multicolumn{2}{|c|}{ Weight per cent } & & & & & & & & \\
\hline Pt & 1.10 & $\mathrm{Ag}$ & 21.91 & 24.40 & 25.76 & 23.97 & 9.40 & 9.23 & 8.92 & 9.05 \\
\hline $\mathrm{Ag}$ & - & $\mathrm{Cu}$ & - & 0.05 & 0.06 & - & 0.10 & 0.00 & 0.00 & 0.00 \\
\hline $\mathbf{P d}$ & 3.84 & $\mathrm{Te}$ & 0.10 & - & - & - & - & - & - & - \\
\hline $\mathrm{Bi}$ & 0.78 & $\mathrm{Hg}$ & 7.63 & 8.74 & 9.24 & 9.29 & nd & nd & nd & nd \\
\hline $\mathrm{Cu}$ & 2.34 & $A u$ & 71.18 & 65.97 & 64.96 & 66.51 & 89.37 & 90.41 & 91.24 & 90.60 \\
\hline $\mathbf{S b}$ & 4.45 & TOTAL & 100.82 & 99.16 & 100.02 & 99.77 & 98.87 & 99.64 & 100.16 & 99.65 \\
\hline $\mathrm{Ni}$ & 0.22 & & & & & & & & & \\
\hline Te & 36.90 & & & & & & & & & \\
\hline $\mathrm{Hg}$ & 50.42 & & & & & & & & & \\
\hline $\mathrm{Au}$ & - & & & & & & & & & \\
\hline \multirow[t]{2}{*}{ TOTAL } & 100.05 & & & & & & & & & \\
\hline & \multicolumn{2}{|c|}{ Atomic concentration } & & & & & & & & \\
\hline $\mathrm{Pt}$ & 0.85 & $\mathrm{Ag}$ & 33.66 & 37.37 & 38.79 & 36.65 & 16.08 & 15.73 & 15.17 & 15.44 \\
\hline$P d$ & 5.44 & $\mathrm{Cu}$ & - & 0.12 & 0.16 & - & 0.29 & - & - & - \\
\hline $\mathrm{Ni}$ & 0.57 & $\mathrm{Te}$ & 0.13 & - & - & - & - & - & - & - \\
\hline $\mathrm{Cu}$ & 5.55 & $\mathrm{Hg}$ & 6.31 & 7.19 & 7.48 & 7.64 & - & - & - & - \\
\hline $\mathrm{Sb}$ & 5.51 & $\mathrm{Au}$ & 59.90 & 55.32 & 53.57 & 55.70 & 83.63 & 84.27 & 84.83 & 84.56 \\
\hline Te & 43.61 & & & & & & & & & \\
\hline $\mathrm{Hg}$ & 37.90 & & & & & & & & & \\
\hline $\mathrm{Bi}$ & 0.56 & & & & & & & & & \\
\hline
\end{tabular}

$\because$ below detection limit; nd: not determined

metal ratio close to 1 , and a possible formula of $\left(\mathrm{Pd}_{0.55} \mathrm{Ag}_{0.37} \mathrm{Ni}_{0.04} \mathrm{Pt}_{0.01}\right)_{\Sigma 0.97}\left(\mathrm{Te}_{0.47} \mathrm{Sb}_{0.42} \mathrm{Bi}_{0.15}\right)_{\Sigma 1.04}$, but these data must be considered with caution because of the small size of the analyzed particle. It is worth noting that Ag was not detected in any other PGM composition.

\section{Gold-silver alloy and silver minerals}

Several grains of gold-silver alloy were identified in type-2A assemblages, occurring as small inclusions $(2-4 \mu \mathrm{m})$ in pyrrhotite, and as larger grains $(<35 \mu \mathrm{m})$ within ferrian chromite crystals. Their chemical composition (see selected data in Table 11) varies from one grain to another and among samples. One sample of massive sulfide (BLR96) contains gold with high $\mathrm{Hg}$ (Au 46.8-60.2, Ag 33.2-43.5 and $\mathrm{Hg} \mathrm{6.3-8.3} \mathrm{at. \% ),}$ associated with coloradoite (HgTe) and hessite $\left(\mathrm{Ag}_{2} \mathrm{Te}\right.$, Table 11). In another sample (BLR83), gold grains are free of $\mathrm{Hg}$, and the atomic proportions are $\mathrm{Au}_{81.0-83.5}$ $\mathrm{Ag}_{14.9-15.9}$.

\section{DiscusSION}

Two different styles of PGE mineralization can be identified in the Baula Complex. Type 1 is magmatic, and type 2 (variants A and B) is hydrothermal. Both are associated with the Bangur gabbro, which has a zircon age of $3121 \pm 3 \mathrm{Ma}$ (mean weighted age, Augé et al., unpubl. data).

\section{Magmatic mineralization}

Type-1 mineralization in the Bangur Gabbro occurs in a sulfide-free magmatic environment. The PGE-bearing facies contains dunite and chromitite blocks extracted mechanically from the ultramafic formation by the intrusive gabbro. Chromite, in the form of chromitite nodules, can constitute up to $50 \%$ of the rock, giving the PGE-bearing facies a brecciated appearance. This type of mineralization is dominated by $\mathrm{Pt}(\mathrm{Pt} / \mathrm{Pd}$ in the range 8-9), with anomalous $\mathrm{Rh}$, and a PGM assemblage dominated by isoferroplatinum, braggite and malanite. PGM are found as inclusions in pyroxene and plagioclase, which suggests that they crystallized early in the evolution of the magma. PGM are also associated with chromite nodules, but only as Ru-Os sulfides. This description consists of a common mode of occurrence for laurite in any chromitite. It should be noted that Page $e t$ al. (1985) reported compositions of "Baula chromitite" for PGE and concluded, on the basis of very low PGE content and a chondrite-normalized PGE pattern presenting a negative slope, that the "chromitites from Baula developed from a magma with very similar PGE contents to those that produced ophiolitic chromitite".

The Pt-rich zone has not yet been traced in the field because of the lack of outcrop. The zone appears to be discontinuous, its actual thickness varying between 50 $\mathrm{cm}$ and $1 \mathrm{~m}$, and it is located at a maximum distance of $50 \mathrm{~m}$ from the gabbro-peridotite contact. In spite of a 
detailed study, no PGE anomaly was detected in the ultramafic part of the complex, or in the chromitite layers (except for a few hundred ppb Ru and Os in the latter).

At this stage of the study, there can be only speculation concerning the origin of the PGE mineralization. Available evidence indicates that the ultramafic rocks and chromitites were incorporated into the mafic magma at very high temperatures (before plagioclase crystallization because the chromite composition has reequilibrated with the magma). There is also a close relationship between the PGE mineralization and chromitite nodules, and PGM are included in pyroxenes.

There are two main possibilities to explain these observations: 1) the source of the PGE was the ultramafic suite incorporated into the gabbro, or 2) the source of the PGE was the gabbro itself, with massive and local precipitation of PGM being provoked by sudden changes in physicochemical conditions due to the incorporation and partial digestion of ultramafic material.

Considering the absence of any detectable $\mathrm{Pt}$ anomaly in the peridotite, the second possibility appears more favorable. The PGM mineralogy is characteristic of high-temperature, magmatic sulfide-free PGE mineralization, and shows striking similarities to some Bushveld Complex occurrences (UG2, Platreef), with braggite, laurite and sperrylite. There is also a similarity to the orthomagmatic stage in the Great Dyke, Zimbabwe, as described by Coghill \& Wilson (1993).

\section{Hydrothermal mineralization}

Type-2 mineralization can be subdivided into 1) Type-2A, in which the PGE are associated with BMS mineralization, and dominated by $\mathrm{Pd}(\mathrm{Pt} / \mathrm{Pd} 0.5)$, and the PGM are mainly sudburyite and minerals from the system $\mathrm{Pd}-\mathrm{Bi}-\mathrm{Te}-\mathrm{Sb}$, and 2) Type $2 \mathrm{~B}$, where BMS are absent, the $\mathrm{PGE}$ are dominated by $\mathrm{Pt}(\mathrm{Pt} / \mathrm{Pd}$ in the range 2-3), and PGM from the system $\mathrm{Pt}-\mathrm{Sb}-\mathrm{As}$ coexist with $\mathrm{Pd}$ antimonides.

This second category of assemblage (types $2 \mathrm{~A}$ and $2 \mathrm{~B})$ is restricted to the hydrothermally altered matrix of the breccia zone. The two subtypes occur together in the field (both can be found in the same outcrop) and can be distinguished only at the hand-specimen scale.

There is plentiful evidence that this second category of mineralization is related genetically to the hydrothermal event that affected the matrix of the breccia zone. The PGM and BMS are systematically associated with hydrous silicates, such as amphiboles, micas, and chlorites, and with ferrian chromite, and textural investigations show that all the ore phases, base metals, gold and PGM are contemporaneous and related to the same hydrothermal mineralizing event.

Lerouge et al. (2000) and Augé et al. (unpubl. data) have shown that the hydrous minerals were formed during the late magmatic evolution of the Baula gabbro, without the introduction of external fluids. The only flu- ids involved were deuteric, and the abundance of hydrous silicates indicates that the residual phase was dominated by fluid. This conclusion is based on $\mathrm{O}$ and $\mathrm{H}$ isotope studies, which indicate that the hydrous minerals are close to the magmatic water box (Taylor 1987). Similarly, the $\delta^{34} \mathrm{~S}$ of the sulfides (chalcopyrite and a few data for pentlandite and pyrrhotite) are homogeneous, ranging from -0.8 to $+1.4 \%$. This range of values, quite close to $0 \%$, is consistent with a magmatic origin for sulfur in the fluids (Taylor 1987), without any contribution from the country rocks. There is no evidence that the BMS assemblage could be magmatic in the sense of resulting from sulfide immiscibility in silicate mafic magma. On the contrary, the data presented indicate that the BMS are related to a fluid-rich, hydrothermal stage, with crystallization temperatures (indicated by cobaltite-gersdorffite compositions) in the range $300^{\circ}-500^{\circ} \mathrm{C}$.

\section{Type $2 A$ versus Type $2 B$}

There is no marked difference in terms of silicate and oxide assemblages between mineralization of types $2 \mathrm{~A}$ and $2 \mathrm{~B}$, and both show evidence of the same hydrothermal processes. Differences in BMS - PGM assemblages are important (Table 1), but there is no real spatial separation between the two. This can be interpreted as indicating their crystallization from fluids of different compositions (at least in terms of minor and trace elements), or alternatively as marking an evolution in the composition of the fluid. One possible scenario is a first stage with crystallization of Pt-dominant PGM, followed by a later stage with the formation of BMS and PGM in the system Pd-Sb-Te-Bi. This possible evolution in the nature of the fluid may also partly explain the different base-metal sulfide assemblages observed in the Breccia zone.

\section{PGE and PGM in the hydrothermal system}

Many occurrences of hydrothermal PGE deposits, or deposits showing hydrothermal overprinting, are described in the literature, and various physicochemical conditions have been envisaged that, in many cases, correspond to specific PGM-BMS assemblages. The common point in the minerals deriving from hydrothermal processes (whatever the temperatures of formation and origins of the fluid) seems to be the association of $\mathrm{Pd}$ (and to a lesser extent $\mathrm{Pt}$ ) with elements such as Te, $\mathrm{Sb}, \mathrm{Bi}, \mathrm{As}, \mathrm{Hg}, \mathrm{Sn}$, etc. It is reasonable to envisage that these elements are concentrated in hydrothermal solutions (Evstigneeva \& Tarkian 1996) and that they precipitate as complex platinum-group minerals. One of the favored forms of PGE transport in such solutions is chloride, and the solubility sequence for $\mathrm{PGE}$ at $25^{\circ} \mathrm{C}$ is $\mathrm{Pd}$ $>\mathrm{Pt}>\mathrm{Os}>\mathrm{Ir}$ (Mountain \& Wood 1988). At higher temperatures, $\mathrm{Pt}$ and $\mathrm{Pd}$ only become highly soluble in very acidic and oxidizing $\mathrm{Cl}$-rich aqueous fluids (Wood 
1987, Gammons et al. 1992, Gammons 1996). The common association of $\mathrm{Cu}$ with $\mathrm{Pd}$ is due to the fact that $\mathrm{Cu}^{+}, \mathrm{Pt}^{2+}$ and $\mathrm{Pd}^{2+}$ have the same affinity for common ligands.

Several of the PGM found in the Baula Complex are also recorded from the Bushveld Complex, where Pt$\mathrm{Pd}$ bismuthotellurides are abundant in parts of the Critical Zone, but Pt-Pd antimonides are extremely rare (Kinloch 1982, McLaren \& De Villiers 1982). Kingston \& El-Dosuky (1982) described a single occurrence of mertieite-II in the Merensky Reef. The only place in the Bushveld Complex where Pt-Pd antimonides (geversite, stibiopalladinite and undetermined minerals) are abundant is in dunite pipes, where high activity of a volatile phase is inferred (Tarkian \& Stumpfl 1975, Peyerl 1982). This assemblage is comparable with type-2B (sulfide-free) assemblages in the Baula Complex.

$\mathrm{Pd}-\mathrm{Pt}$ tellurides and bismuthotellurides are abundant in the Noril'sk $\mathrm{Cu}-\mathrm{Ni}$ sulfide ores. In the opinion of Genkin \& Evstigneeva (1986), differentiation of the magmatic sulfide melt during the formation of massive ores can lead to the separation of a large volume of $\mathrm{Cu}-$ rich melt in which Pt, $\mathrm{Pd}$, and other elements such as $\mathrm{Sn}, \mathrm{Pb}, \mathrm{As}, \mathrm{Sb}$ and $\mathrm{Bi}$ become concentrated, together with volatile elements such as $\mathrm{Cl}$. Crystallization of this melt will then produce bodies of massive chalcopyrite followed by a late episode of PGE mineralization containing Pt-Pd tellurides and bismuthotellurides. In the veinlet-disseminated and breccia ores, PGM (particularly Pd-Pt tellurides and bismuthotellurides) are formed under hydrothermal conditions. Such a process, where volatile elements become enriched in late hydrothermal fluids, is similarly envisaged at Baula for type2A (BMS-Cu-rich) and -2B (BMS-free) mineralization.

The mineralogy of the PGE in the Sudbury Complex shows many similarities to the PGM in type-2A mineralization at Baula. Sudbury is the complex where sudburyite, which is the most common mineral observed at Baula, was first described by Cabri \& Laflamme (1974). These authors also reported that the majority of the PGM at Sudbury occur as tellurides, bismuth tellurides, bismuthides and antimonides. They noted a close relationship between $\mathrm{Bi}, \mathrm{Te}, \mathrm{Sb}$ and $\mathrm{Pd}, \mathrm{Pt}, \mathrm{Ag}$. A similar association is noted in the Baula Complex, although here $\mathrm{Bi}, \mathrm{Te}$ and $\mathrm{Sb}$ show a much stronger relationship with Pd than with Pt and Ag. Despite these similarities between Sudbury and Baula in terms of PGE mineralogy, there are significant differences. In particular, the proportions of PGM are different; for example, michenerite $(\mathrm{PdBiTe})$ and moncheite $\left[\mathrm{Pt}(\mathrm{Te}, \mathrm{Bi})_{2}\right]$, which together with sperrylite are the most abundant PGM at Sudbury, are lacking or extremely rare in Baula, whereas geversite, mertieite-II and merenskyite are abundant at Baula, but rare at Sudbury.

Sudbury is one of the complexes where hydrothermal remobilization of $\mathrm{Cu}-\mathrm{Ni}-\mathrm{PGE}$ has been studied in detail. Farrow \& Watkinson (1997) described the precious-metal mineralization in footwall deposits from
Sudbury and showed that the PGM are dominantly Ptand Pd-rich bismuthides, selenides and bismuth tellurides. Compositional variations within grains of a given PGM provide evidence that there were fluctuations in the fluid composition, temperature and pulses of hydrothermal activity. Tellurides occur as discrete minerals in BMS, silicates and oxides. The sulfides locally appear to overgrow the alteration-induced silicates, suggesting that hydrothermal fluids existed in the system and formed an assemblage of alteration minerals dominated by silicates before the separation of a sulfide-rich hydrothermal fluid during the final stages of fluid evolution. Farrow \& Watkinson (1997) suggested that the fluids were derived from country rocks and that late magmatic fluids may have played a minor role, which is the opposite of conclusions developed in this paper for Baula.

Many of the processes and minerals in the PGM assemblages described from the Baula Complex are present in both the high-temperature hydrothermal occurrences mentioned above and in low-temperature hydrothermal deposits. For example, stibiopalladinite, sudburyite and complex palladium-antimony selenides, palladium-bismuth selenides and bismuthian stibiopalladinite occur in the low-temperature Coronation Hill mineralization (Mernagh et al. 1994). Similarly, a palladium telluride, a palladium-bismuth telluride and rhodium sulfarsenides are described in pitchblende-rich veins in Northwest Territories, Canada (Gandhi \& Paktunc 1989).

\section{Synthesis}

Most of the "hydrothermal" deposits described above are the result of "remobilization" of primary BMS-PGE-rich assemblages or of "redistribution" after alteration and metamorphism. Platinum-palladium minerals, as part of the complex system Pt-Pd-Sb-Te$\mathrm{Bi}-\mathrm{As}$, can form in a wide range of conditions and environments.

There is evidence of orthomagmatic PGE mineralization in the Baula Gabbro (Type 1), but no evidence that the products of this mineralization were remobilized. Similarly, the BMS mineralization is hydrothermal, but there is no evidence of sulfide remobilization. On the contrary, type- 2 assemblages of BMS and PGM have crystallized from a fluid-rich phase during a late (postmagmatic) stage. This fluid phase was generated by the crystallization of silicates at a magmatic stage in the gabbro and became concentrated in the breccia zone at the top of the magmatic system (Genna and Augé, unpubl. data). The exsolved fluid phase became progressively enriched in volatiles, $\mathrm{Cu}, \mathrm{S}$, semimetals and PGE, and "autohydrothermally" altered the mineral assemblages in the gabbro, thereby transforming the chromite crystals into ferrian chromite, a complex micrometric assemblage of different oxides. Type-2 BMS and PGM crystallized from this fluid phase and are thus locally 
intimately associated with ferrian chromite. A very similar process was proposed by Coghill \& Wilson (1993) for the Great Dyke (but they invoked "microscale" remobilization of PGM, not observed in the Baula Complex), and by Pirrie et al. (2000), where a combined orthomagmatic-hydromagmatic origin is proposed for the Mull Complex in Scotland.

Evidence from the Baula Complex supports the existence of both an orthomagmatic stage of PGE mineralization and a postmagmatic hydrothermal stage of mineralization, but there is no evidence that the second stage is the result of remobilization of the first. We conclude, therefore, that there were two separate mineralizing events in a single, but complex, evolution of the magma.

This model is significantly different from the model recently proposed by Mondal et al. (2001), who envisaged that the type-2A mineralization (hydrothermal according to our model), was developed by "magmatic processes" in a hydrid magma, resulting from partial incorporation of serpentinized chromite-bearing ultramafic blocks in a younger gabbroic magma. Mondal et $a l$. also suggested that the gabbroic magma was emplaced within a pre-existing breccia zone. Data presented here (also Genna and Augé, unpubl. data) show clearly that the emplacement of the gabbroic magma (the Bangur Gabbro) is contemporaneous with the formation of the breccia zone.

\section{ConCLusion}

Two very distinct types of mineralization have been identified in the Baula Complex, both related to a gabbro body that partly intruded the ultramafic complex. The first is characterized by a high $\mathrm{Pt} / \mathrm{Pd}$ ratio and occurs close to the contact between gabbro and the ultramafic rocks, where chromitite xenoliths are found in the gabbro. The PGM (isoferroplatinum, braggite, sperrylite, laurite, malanite) occur as inclusions in magmatic cumulus silicates (plagioclase and pyroxene). This type of mineralization is considered orthomagmatic. The ubiquitous presence of chromitite xenoliths in the PGErich gabbroic facies suggests that PGM crystallization was associated with interactions between the gabbro and the host ultramafic unit, but the source of the PGE was the gabbroic magma.

At the top of the intrusion, the gabbro was emplaced along a shear zone, causing magmatic brecciation of the host ultramafic rock, and resulting in a breccia zone composed of dunite, pyroxenite and chromitite blocks from the surrounding rocks in a gabbro matrix. The matrix was subjected to strong hydrothermal alteration, and the second type of PGE mineralization resulted from this hydrothermal event. The fluids involved were deuteric and, depending on their composition, produced two different types (2A and $2 \mathrm{~B}$ ) of PGE mineralization associated with hydrous silicates. Type-2A mineralization is characterized by low Pt/Pd values, the PGM be- longing to the complex system $\mathrm{Pd}-\mathrm{As}-\mathrm{Sb}-\mathrm{Bi}-\mathrm{Te}$, and by the presence of complex assemblages of base-metal sulfides. Textural observations show that the PGM and BMS were produced during the same mineralizing event. Type-2B mineralization occurs in sulfide-free rock, shows Pt/Pd values between 2 and 3, and the PGM are dominated by phases in the system $\mathrm{Pt}-(\mathrm{Pd})-\mathrm{As}-\mathrm{Sb}$.

There is no evidence that type-2 mineralization is the result of remobilization of pre-existing mineralization. It is more likely that the hydrothermal fluid became progressively enriched in PGE and volatile elements during its evolution, and the source of the PGE and other metals was the gabbro itself.

\section{ACKNOWLEDGEMENTS}

Most of this work was conducted during a joint GSIBRGM project, and we thank the Geological Survey of India for permitting publication of the results. We also thank the companies FACOR, IMFA and OMC for their logistical support and authorization to work on their properties, as well as their geologists for advice and guidance. A special thanks is extended to K.N.G. Rao (FACOR) for his knowledge of the complex. O. Legendre, A.Y. Barkov, R.F. Martin and an anonymous reviewer are thanked for their constructive comments on the manuscript. The English text was kindly edited by Kevan Ashworth. It is also an honor to dedicate this work to our friend Louis Cabri.

\section{REFERENCES}

Augé, T., Cocherie, A., Genna, A., Armstrong, R. \& Guerrot, C. (2002): Age of the Baula PGE mineralization (Orissa, India) and its implication concerning the evolution of the Singhbhum Craton. Precamb. Res. (in press).

\& LegendRe, O. (1994): Platinum-group element oxides from the Pirogues ophiolitic mineralization, NewCaledonia - origin and significance. Econ. Geol. 89, 14541468 .

\& Maurizot, P. (1995): Stratiform and alluvial platinum mineralization in the New Caledonia ophiolite complex. Can. Mineral. 33, 1023-1045.

SAlpeteur, I., Mukherjee, M.M. \& Patra R.N. (1999): Platinum-group element mineralization in the breccia zone of the Baula Nuasahi Complex, Orissa, India. In Mineral Deposits: Processes to Processing (C.J. Stanley et al., eds.). Balkema, Dordrecht, The Netherlands (701704).

BANERJEe, P.K. (1972): Geology and geochemistry of the Sukinda ultramafic field, Cuttack district, Orissa. Geol. Surv. India, Mem. 103.

Mahakud, S.P., Bhattacharyya, A.K. \& MoHANTY, A.K. (1987): On the northern margin of the Eastern Ghats in Orissa. Geol. Surv. India, Rec. 118, 1-8. 
Barkov, A.Y., Pakhomovskit, Y.A., \& Men'shikov, Y.P. (1995) : Zoning in the platinum-group sulfide minerals from the Lukkulaisvaara and Imandrovsky layered intrusions, Russia. Neues Jahrb. Mineral., Abh. 169, 97117.

Beaudoin, G., Laurent, R. \& Ohnenstetter, D. (1990): First report of platinum-group minerals at Blue Lake, Labrador Trough, Quebec. Can. Mineral. 28, 409-418.

BURKHARD, D.J.M. (1993): Accessory chromium spinels: their coexistence and alteration in serpentinites. Geochim. Cosmochim. Acta 57, 1297-1306.

Burns, P.C., Hawthorne, F.C., Libowitzky, E., Bordes, N. \& EwING, R.C. (1997): Donathite discredited: a mixture of two spinels. Neues Jahrb. Mineral., Monatsh., 163-174.

CABRI, L.J. \& Laflamme, J.H.G. (1974): Sudburyite, a new palladium-antimony mineral from Sudbury, Ontario. Can. Mineral. 12, 275-279.

$\&$ (1976): The mineralogy of the platinum-group elements from some copper-nickel deposits of the Sudbury area, Ontario. Econ. Geol. 71, 1159-1195.

, STEWART, J.M., TURNER, K. \& SKInNER, B.J. (1978): On cooperite, braggite, and vysotskite. Am. Mineral. 63, 832-839.

Coghill, B.M. \& Wilson, A.H. (1993): Platinum-group minerals in the Selukwe subchamber, Great Dyke, Zimbabwe: implications for PGE collection mechanisms and post-formational redistribution. Mineral. Mag. 57, 613633

Das, N.R., Lahiri, S, Basu, D., Baidya, T.K. \& ChakraBORTY, K.L. (1994): Nuclear techniques to study the noble metals in the chromite-sulphide association of Nuasahi, Orissa, India. Nucl. Geophys. 8, 85-90.

Evstigneeva, T., Genkin, A.D. \& Kovalenker, V.A. (1976): Sobolevskite, a new bismuthide of palladium, and the nomenclature of minerals of the system PdBi-PdTe-PdSb. Int. Geol. Rev. 18, 856-866.

\& TARKIAN, M. (1996): Synthesis of platinum-group minerals under hydrothermal conditions. Eur. J. Mineral. $8,549-564$

FARrow, C.E.G. \& WATKINSON, D.H. (1997): Diversity of precious-metal mineralization in footwall $\mathrm{Cu}-\mathrm{Ni}-\mathrm{PGE}$ deposits, Sudbury, Ontario: implications for hydrothermal models of formation. Can. Mineral. 35, 817-839.

FEATHER, C.E. (1976): Mineralogy of platinum-group minerals in the Witwatersrand, South Africa. Econ. Geol. 71, 1399 1428 .

Furuseth, S., Selte, K. \& KJekshus A. (1967): On the solid solubility and structural properties of $\mathrm{PdAs}_{2-\mathrm{x}} \mathrm{Sb}_{\mathrm{x}}$, $\mathrm{PtP}_{2-\mathrm{x}} \mathrm{As}_{\mathrm{x}}, \mathrm{PtP}_{2-\mathrm{x}} \mathrm{Sb}_{\mathrm{x}}, \mathrm{PtP}_{2-\mathrm{x}} \mathrm{Bi}_{\mathrm{x}}, \mathrm{PtAs}_{2-\mathrm{x}} \mathrm{Sb}_{\mathrm{x}}, \mathrm{PtAs}_{2-\mathrm{x}} \mathrm{Bi}_{\mathrm{x}}$
$\mathrm{PtSb}_{2-\mathrm{x}} \mathrm{Bi}_{\mathrm{x}}, \mathrm{Pd}_{1-\mathrm{m}} \mathrm{Pt}_{\mathrm{m}} \mathrm{As}_{2}, \mathrm{Pd}_{1-\mathrm{m}} \mathrm{Pt}_{\mathrm{m}} \mathrm{Sb}_{2}, \mathrm{Pd}_{1-\mathrm{m}} \mathrm{Au}_{\mathrm{m}} \mathrm{Sb}_{2}$ and $\mathrm{Pt}_{1-\mathrm{m}} \mathrm{Au}_{\mathrm{m}} \mathrm{Sb}_{2}$. Acta Chem. Scand. 21, 527-536.

GAMmons, C.H. (1996): Experimental investigations of the hydrothermal geochemistry of platinum and palladium. 5 . Equilibria between platinum metal, $\mathrm{Pt}(\mathrm{II})$, and $\mathrm{Pt}(\mathrm{IV})$ chloride complexes at 25 to 300 degrees C. Geochim. Cosmochim. Acta 60, 1683-1694.

BLoom, M.S. \& YU, Y. (1992): Experimental investigation of the hydrothermal geochemistry of platinum and palladium. I. Solubility of platinum and palladium sulfide minerals in $\mathrm{NaCl} / \mathrm{H}_{2} \mathrm{SO}_{4}$ solutions at $300^{\circ} \mathrm{C}$. Geochim. Cosmochim. Acta 56, 3881-3894.

Gandhi, S.S. \& Paktunc, A.D. (1989): Au, Pt, and Pd in pitchblende and copper sulphide veins at the Rah, Far, and Jaciar prospects, northern Bear Province, Northwest Territories. Geol. Surv. Can., Pap. 89-1C, 243-253.

Genkin, A.D. \& Evstigneeva, T.L. (1986): Associations of platinum-group minerals of the Noril'sk copper-nickel sulfide ores. Econ. Geol. 81,1203-1212.

Gervilla, F., Sanchez Anguita, A., Acevedo, R.D., Hach Alí, P.F. \& PANIAGUA, A. (1997): Platinum-group element sulpharsenides and Pd bismuthotellurides in the metamorphosed Ni-Cu deposit at Las Aguilas (Province of San Luis, Argentina). Mineral. Mag. 61, 861-877.

Hoffman, E. \& MacLean, W.H. (1976): Phase relations of michenerite and merenskyite in the $\mathrm{Pd}-\mathrm{Bi}-\mathrm{Te}$ system. Econ. Geol. 71, 1461-1468.

Johan, Z., Ohnenstetter, M., Slansky, E., Barron, L.M. \& SUPPEL, D. (1989): Platinum mineralization in the Alaskantype intrusive complexes near Fifield, New South Wales, Australia. 1. Platinum-group minerals in clinopyroxenites of the Kelvin Grove Prospect, Owendale intrusion. Mineral. Petrol. 40, 289-309.

Kingston, G.A. \& El-Dosuky, B.T. (1982): A contribution on the platinum-group mineralogy of the Merensky Reef at the Rustenburg platinum mine. Econ. Geol. 77, 1367-1384.

KINLOCH, E.D. (1982): Regional trends in the platinum-group mineralogy of the Critical Zone of the Bushveld Complex, South Africa. Econ. Geol. 77, 1328-1347.

KLemm, D.D. (1965): Synthesen und Analysen in den Dreiecksdiagrammen FeAsS-CoAsS-NiAsS und $\mathrm{FeS}_{2}-$ $\mathrm{CoS}_{2}-\mathrm{NiS}_{2}$. Neues Jahrb. Mineral., Abh. 103, 205-255.

Lerouge, C., Bailly, L., Augé, T. \& Salpeteur, I. (2000): Hydrothermal alteration associated with the PGE mineralisation of the Baula Complex (Orissa, India) - mineralogy and stable isotopes. In Metallogeny 2000, Review and Perspectives, Symp. Bernard Poty, Metallogeny Group ILG Nancy, 85 (abstr.).

McCallum, M.E., Loucks, R.R., Carlson, R.R., Cooley, E.F. \& Doerge, T.A. (1976): Platinum metals associated with hydrothermal copper ores of the New Rambler mine, 
Medicine Bow Mountains, Wyoming. Econ. Geol. 71, 1429-1450.

MCLAREN, C.H. \& De Villiers, J.P.R. (1982): The platinumgroup chemistry and mineralogy of the UG-2 chromitite layer of the Bushveld Complex. Econ. Geol. 77, 13481366.

MERKLE, R.K.W. \& GRÄSER, P.P.H. (1998): On the meaning of chromium and iron contents in laurite. In Proc. 8th Int. Platinum Symp. (Rustenburg), 259-261.

Mernagh, T.P., Heinrich, C.A., Leckie, J.F., Carville, D.P., Gilbert, D.J., VALENTA, R.K. \& WyBorn, L.A.I. (1994): Chemistry of low-temperature hydrothermal gold, platinum, and palladium ( \pm uranium) mineralization at Coronation Hill, Northern-Territory, Australia. Econ. Geol. 89, 1053-1073.

Mitra, S., Pal, T., Maity P.K. \& Moon, Hi Soo (1992): Ferritchromit and its opto-chemical behaviour. Mineral. J. 16, 173-186.

Mohanty, J.K. \& Sahoo, R.K. (1996): Mineralogical and chemical characteristics of the serpentinites from BoulaNausahi igneous complex, Orissa. J. Geol. Soc. India 48, 161-170.

Mondal, S.K. \& BAIDYA, T.K. (1997): Platinum-group minerals from the Nuasahi ultramafic-mafic complex, Orissa, India. Mineral. Mag. 61, 902-906.

, RAO, K.N.G. \& GLASCOCK M.D. (2001): PGE and Ag mineralization in a breccia zone of the Precambrian Nuasahi ultramafic-mafic complex, Orissa, India. Can. Mineral. 39, 979-996.

Mountain, B.W. \& Wood, S.A. (1988): Chemical controls on the solubility, transport, and deposition of platinum and palladium in hydrothermal solutions: a thermodynamic approach. Econ. Geol. 83, 492-510.

Mukherjee, M.M., Patra, R.N., Salpeteur, I. \& Augé, T. (1998): Baula-Nuasahi ultramafic complex and PGE, a new style of mineralisation, Orissa, India. S. Afr. Inst. Mining Metall., Publ. S18, 279-280.

MukHerJeE, S. \& HALdAR, D. (1975) Sedimentary structures displayed by the ultramafic rocks of Nausahi, Keonjhar district, Orissa, India. Mineral. Deposita 10, 109-119.

NANDA, J.K., PAtra, R.N. \& Mishra, R.N. (1996): Petrogenetic history of the platiniferous magmatic breccia zone in Baula Igneous Complex: a conceptual model for PGM localisation. In Workshop on Geology and Exploration of Platinum Group, Rare Metal and Rare Earth Elements (Calcutta). Geol. Surv. India, 17-19.

Ohnenstetter, D., Watkinson, D.H., Jones, P.C. \& TALKINGTON, R.W. (1986): Cryptic compositional variation in laurite and enclosing chromite from the Bird River Sill, Manitoba. Econ. Geol. 81,1159-1168.
Page, N.J., BAnerJi, P.K. \& HaffTy, J. (1985): Characterization of the Sukinda and Nausahi ultramafic complexes, Orissa, India by platinum-group element geochemistry. Precamb. Res. 30, 27-41.

PATRA, R.N. \& MukHERJEe, M.M. (1996): Exploration for PGE in Baula - Nuasahi - Bangur ultramafic complex, Keonjhar District, Orissa. In Workshop on Geology and Exploration of Platinum Group, Rare Metal and Rare Earth Elements (Calcutta). Geol. Surv. India, 7-9.

PeyerL, W. (1982): The influence of the Driekop dunite pipe on the platinum-group mineralogy of the UG-2 chromitite in its vicinity. Econ. Geol. 77, 1432-1438.

Pirrie, D., Power, M.R., Andersen, J.C.O. \& Butcher, A.R. (2000): Platinum-group mineralization in the Tertiary igneous province; new data from Mull and Skye, Scottish Inner Hebrides, UK. Geol. Mag. 137, 651-658.

SAHA, A.K. (1994): Crustal evolution of Singhbhum - North Orissa, Eastern India. Geol. Soc. India, Mem. 27.

Shen, Pouyan, Hwang, Shyh-Lung, Chu, Hao-Tsu \& Jeng, RUEY-CHANG (1988): STEM study of "ferritchromit" from the Heng-Chun chromitite. Am. Mineral. 73, 383-388.

TARKIAN, M. \& STUMPFL, E.F. (1975): Platinum mineralogy of the Driekop mine, South Africa. Mineral. Deposita 10,7185 .

TAYLOR, B.E. (1987): Stable isotope geochemistry of oreforming fluids. In Stable Isotope Geochemistry of LowTemperature Processes (T.K. Kyser, ed.). Mineral. Assoc. Can., Short Course Handbook 13, 337-445.

Thiagarajan, T.A., Thothathiri, G., Rao, M.S. \& RamaCHANDRARAO, M.N. (1989): A report on the investigation for PGM in the Nuasahi chromite belt, Orissa and Sindhuvalli-Talur ultramafic belt, Karnataka. Geol. Surv. India-AMSE Open File Rep.

Verryn, S.M.C. \& Merkle, R.K.W. (1994): Compositional variation of cooperite, braggite, and vysotskite from the Bushveld Complex. Mineral. Mag. 58, 223-234.

Wood, S.A. (1987): Thermodynamic calculations of the volatility of the platinum group elements (PGE): the PGE content of fluids at magmatic temperatures. Geochim. Cosmochim. Acta 51, 3041-3050.

Wylie, A.G., Candela, P.A. \& Burke, T.M. (1987): Compositional zoning in unusual $\mathrm{Zn}$-rich chromite from the Sykesville district of Maryland and its bearing on the origin of "ferritchromit". Am. Mineral. 72, 413-422.

Received September 24, 1999, revised manuscript accepted January 16, 2002. 